\title{
NEW REALITY IN MUSEUM
}

\author{
Zeren ORUÇ \\ İstanbul Kültür Üniversitesi, Sanat Yönetimi Bölümü Yükseklisans Öğrencisi \\ zerenoruc@gmail.com
}

\begin{abstract}
In this study, virtual museums will be examined which considered as product of technology and the changing forms of communication with a structure of beyond time and space. Therefore, history of museum and its relationship with technology examined firstly. Ingress of technology to the museum life, use of technology as quality criteria at last technologic and economic race is demonstrated due to increasing competition and in order to meet the demands of museums. The development of virtual museum, the positive and negative approach towards the virtual museum has been studied. Concept of virtual museum and their types, which is not consensus yet, were tried to explain. Lastly to clarify this study, The Virtual Museum of Iraq selected and examined for reasons that will be explain later and a conclusion has been reached.
\end{abstract}

Keywords: virtual museum, digital museum, e-museum, digitization, technology, art

\section{MÜZEDE YENI GERÇEKLIKK}

ÖZ

$\mathrm{Bu}$ çalışmada zaman ve mekanın ötesindeki yapısıyla teknolojinin ve değişen iletişim biçiminin bir ürünü olan sanal müzeler incelenecektir. Bunun için öncelikle müzenin tarihi ve teknoloji ile kurduğu ilişki incelenmiştir. Teknolojinin müze hayatına girişi, bir kalite kriteri olarak teknolojinin kullanılışı ve sonunda artan rekabet ortamı nedeniyle müzelerin taleplerini karşılamak adına girdiği teknik ve ekonomik yarış ortaya konmuştur. Çalışmanın konusu olan sanal müzelerin gelişimi, sanal müzelere karşı olumlu ve olumsuz yaklaşımlar incelenerek, henüz üzerinde fikir birliğine varılmamış olan sanal müze kavramını ve türleri açıklanıp sanal müzenin aslında ne olduğu açıklanmaya çalışılmıştır. Son olarak çalışmaya açıklık getirmek amacıyla ileride açıklanacak sebeplerle The Virtual Museum of Iraq ( Irak Sanal Müzesi) seçilerek incelenmiş ve bir sonuca varılmıştır

Anahtar Kelimeler: sanal müze, dijital müze, e-müze, dijitalleşme, teknoloji, sanat

\section{GíRIŞ}

İkinci Dünya Savaşı sonrası manevi değerleri değişime uğrayan Batı toplumunda ekonomi ve politika anlayışıyla birlikte sanat anlayışı da değişmeye başlamıştır. Günlük hayatı sanatın bir parçası haline getirmeyi amaçlayan akımlar diğer bir yandan giderek soyutlaşan ve kitleden uzaklaşan sanat, üretim şeklinin de değişmesiyle beklenmeyen bir yola sapmıştır. Ready made ve seri üretime dayanan yeni sanat anlayışı, savaş sonrası ekonomik yaralarını saran toplumda yeni bir yatırım aracı haline gelmeye başlamışır. Yatırım aracı haline gelen sanat yeni bir rekabet ortamını ve kültür endüstrisini yaratmıştır.

İnternetin yaygınlaşması ve teknolojinin ekonomik olarak ulaşılabilir olması sanata yeni bir dokunuş daha getirmiştir. Bu noktadan sonra dijital sanat, internet sanatı gibi türler ortaya çıkmış teknoloji bir çok sanat dalının ayrılmaz parçası haline gelmiştir. Her gün milyonlarca ziyaretçiyi ağırlayan internet yeni bir iletişim aracı haline gelirken bir çok kurum bu durumdan ciddi biçimde etkilenmiştir. İnternet yeni ve daha güçlü bir rekabet ortamı yaratmıştır. Gelişmek isteyen her sektör gerek tanıtım gerek satış amaçlı olarak internete ihtiyaç duymaya başlamıştır. Dijitalleşme ve internet olanakları adeta marka kalitesinin bir unsuru haline gelmiştir. 
Kültür endüstrisinin bir sonucu olarak sanat ve müzeler de bu dijital rekabet ortamından nasibini almıştır. İnternet kullanımının rahatlığı, bilginin ulaşılabilirliği, ücretsiz olması insanın yaşam biçimini değiştirmesi kişileri galeri ve müzelerden uzaklaştırmaya başlamıştır. Evinden çıkmadan her türlü sanat eserini bir tıkla tanımaya çalışan insanların sayısı çoğalmış bunun yanında toplumsal ilgisizliğin artmasıyla da müzelerin ziyaretçi sayısı giderek düşmüştür. Bununla birlikte sanat yatırımına vergi indirimi yapılması, sanatı anlamanın ve eser sahibi olmanın bir prestij, markalaşma sorunu olmaya başlaması gibi sebeplerle büyük kapitaller sanata yaptıkları yatırımları artırmış ve bu yatırımları kamuya açık olması ve kurumsallaşmış güvenilirliğinin olması nedeniyle müzeler üzerinde yoğunlaştırmıştır. Sermayeye dayanan bu müzeler sadece koleksiyonlarıyla değil gıdadan hediyelik eşyaya çeşitli tesisleri de son derece ilgi çekmiş kısa sürede kar getirir hale gelmiştir. Ancak internet ve teknoloji cebimizde taşıdığımız küçük müzelere arşivlerini kurunca, müzelere olan ilgi yine azalmıştır. Teknolojiyi lehine çeviren özel müzeler çok çeşitli şekillerde dijitalleşmiştir. İlk olarak müze rehberini ortadan kaldıran sesli kayıtlar devreye girmiş daha sonraları bunun yeri tüm ziyaretçilere temin edilebilen tabletler almıştır. Bu akıllı müzeler, gelen ziyaretçileri eserlerden çok teknolojiye hayran bıraktırırken internet farklı bir sorumluluk yüklenmiş müzelerin tanıtım ve duyuru aracı olmuştur. Web sitesine sahip olmayan müzeler yarış dışı kalmış, diğer müzeler içinde de web sitesi savaşları başlamıştır. Önceleri koleksiyonları tanıtmak amacıyla kurulan müze web siteleri ve online kataloglar son yıllarda yeni bir müze türünün ortaya çıkmasına öncülük etmiştir: Sanal Müze.

Sanatın ve müzeciliğin çok sesli dünyasında henüz sanal müzenin ne olduğu konusunda kanaat getirilmemiş̧, ayrıca sanal müzenin gerçek bir müze olup olmadığı konusunda anlaşmazlıklar ortaya çıkmıştır. Sanal müzelerin "gerçekliği" tartışma konusuyken bu araştırma boyunca alışılagelmiş müzelere "gerçek müze" kavramı uygun bulunmadığı için "mekansal müze" denilecektir. Literatür tarama yöntemi kullanılarak yapılan bu araştırmanın amacı sanal müze kavramına açıklık getirerek, müze kültüründeki yerini ve bilgi çağındaki önemini ortaya koymaktır.

\section{GEÇMISSTEN GÜNÜMÜZE MÜZE \\ 1.1. Müzelerin Doğușu}

Antik Yunan dilinde "İlham Perisi" anlamına gelen "Mouseion" kelimesinden türeyerek günümüzdeki kullanımına ulaşan "Müze" fikrinin temelleri ilk olarak "Nadire Kabineleri"yle ortaya atılmıştır. Aydınlanma Çağı aristokratlarının topladıkları eşyaları sergileme alışkanlıkları zaman içinde müzelerin kuruluşuna yol açmıştır (<www.e-skop.com>30.10.2015). Sanatın kilise tekelinden tam anlamıyla çıkmamış olması nedeniyle toplanan eşyalar sanat eseri niteliğinde değildir, daha çok egzotik bulunan eşyalar sergilenmiştir. Elbette ki sergilerin ana unsurlarını Haçlı Seferleri'nde yağmalanan eşyalar oluşturmuştur. Medici ailesi gibi sanat ve sanatçı koruyucularının topladığı sanat eserleri "nadire kabineleri" gibi halka açık sergilenmemiş, saray duvarlarında ve aile kasalarında korunmuştur. Orijinal adı "wunderkammer" olan "nadire kabineleri" getirdiği bilgilendirme amaçlı halka açık sergi yaklaşımı sonucunda Avrupa'da müze anlayışı oluşmaya başlamış.

1656'da John Tradescant'ın koleksiyonunun kataloğunu yayınlatarak Avrupa literatüründe müze kavramı bugünkü anlamda kullanılmasını sağlamıştır. Kataloğun adı "Musaeum Trandescantianum"dur. 1677'de Elias Ashmole'un malvarlı̆̆ına geçen koleksiyon, Oxford Üniversitesi'ne gönderilmiştir. Bu koleksiyon için özel bir bina inşa eden üniversite, 1683 'te Ashmolean Museum olarak anılmaya başlamıştır. Ancak müze mevzuatında fikir birliği sağlanamamıştır. 1753'te kurulan British Museum bu koleksiyonu koruma altına almıştır. Başlangıçta girişin ücretsiz olduğu müze daha sonra günlük basılan sınırlı sayıdaki biletlerle ziyaretçi kabul etmiştir (Lewis,2011:24). 


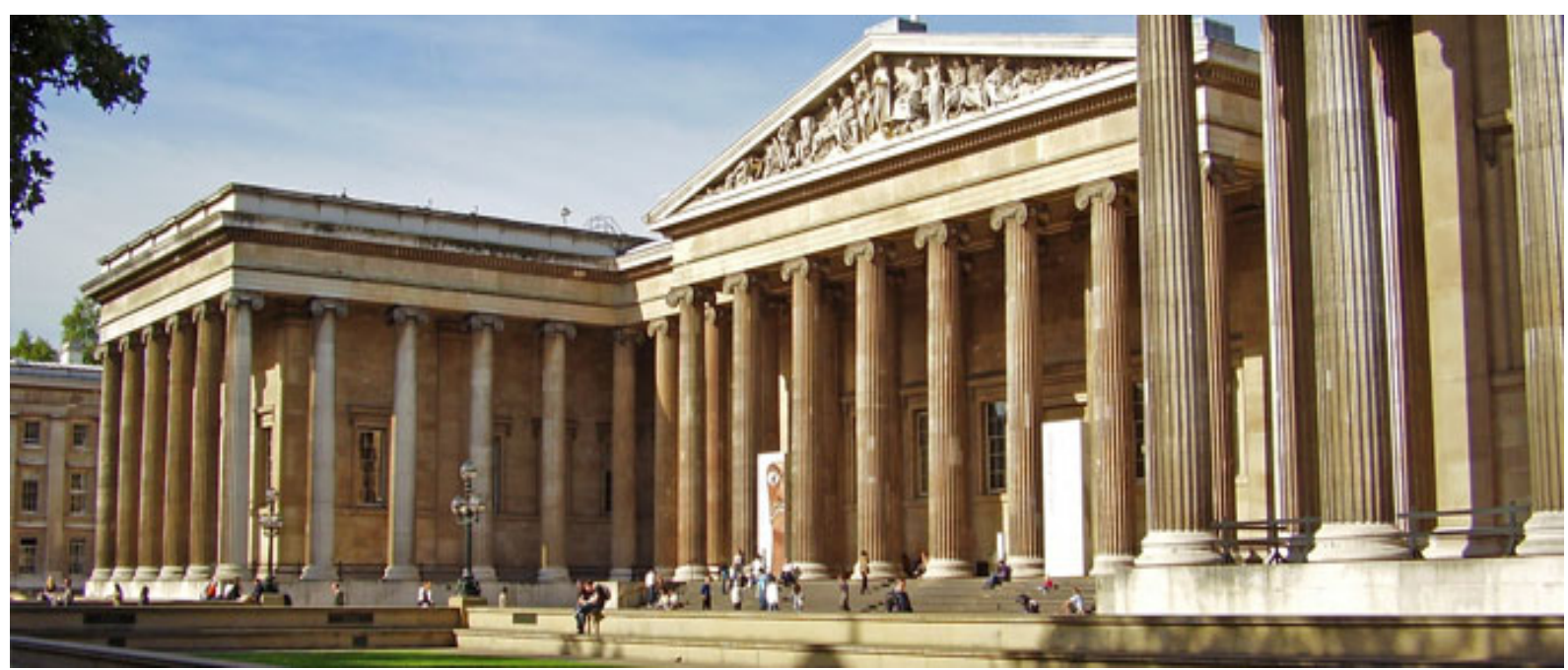

Görsel 1: British Museum - http://travelioo.com/images/united-kingdom/british-museum $(11.11 .2015)$

Bazı görüşlere göre ise British Museum'un sınırlı sayıda ziyaretçiyi kabul etmesi müzelerin tanımında yer alan "halka açık" kavramına uygun bulunmamış bu doğrultuda Avrupa'daki ilk müze Louvre Müzesi (Fransa/1793) kabul edilmiştir. Aynı sebeple İngiltere'de açılan ilk müze 1852'de kurulan Victoria ve Albert Museum olarak kabul edilmiş, enstitü olarak değerlendirilen British Museum ise kapılarını tamamen halka açtıktan sonra müze olarak kabul edilmiştir (Sağdıç, 2008:4).

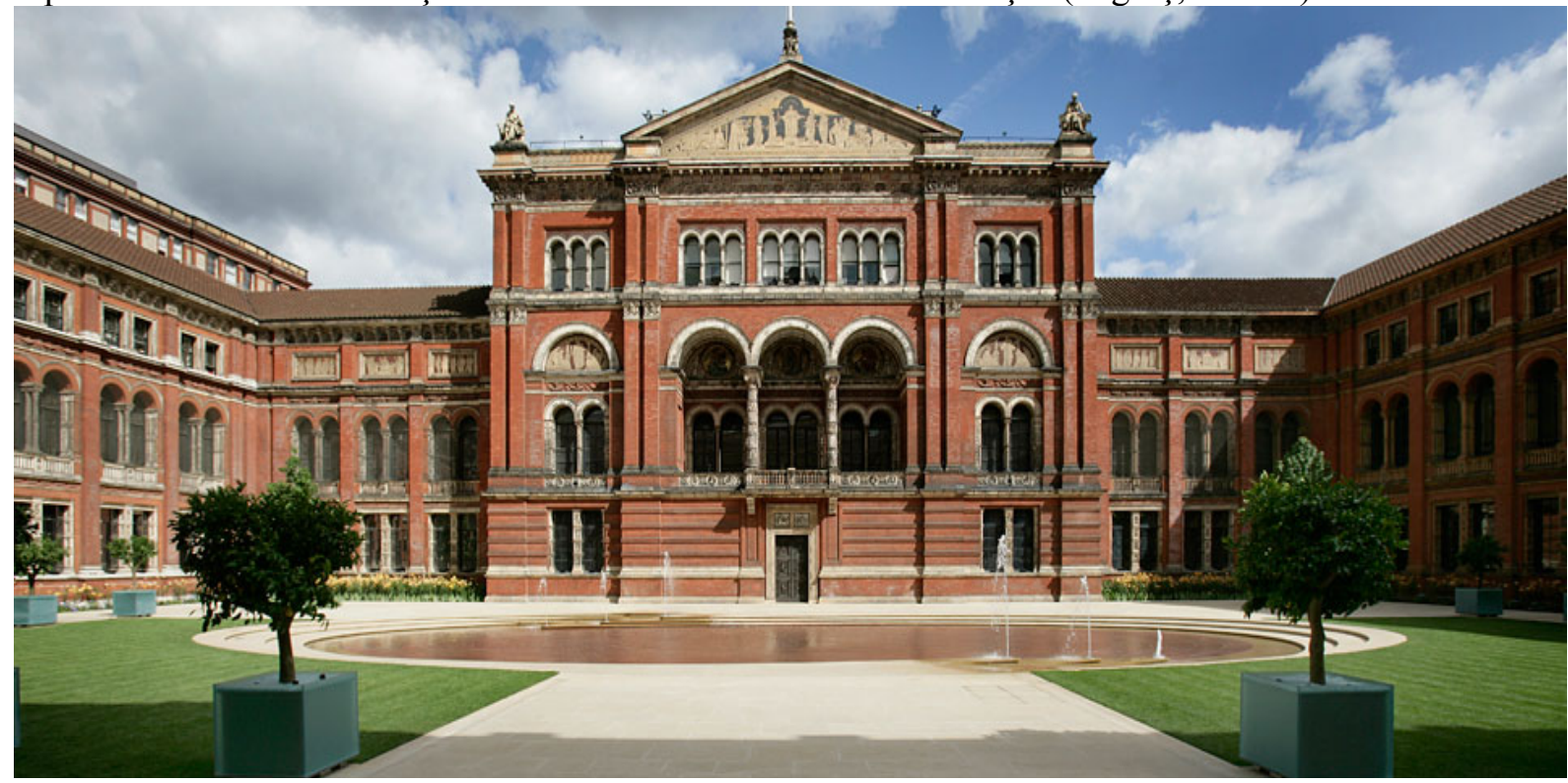

Görsel 2: Victoria and Albert Museum- http:/www.vam.ac.uk/page/a/about-us/ (11.11.2015)

\subsection{Müze ve Türleri}

Birçok farklı tanımı olan müze; kültürel, sanatsal, tarihsel ve bilimsel her türlü bilgiyi koruma ve aktarma amacıyla kamu yararı adına kar kaygısı taşımadan halka sunan kurumdur. Toplama, belgeleme, arşivleme, koruma, sergileme ve eğitim gibi işlevleri olan müzeler her geçen gün birçok anlamda çeşitlenmektedir. Bu müzeler 1995 yılında Uluslararası Müzeler Birliği (ICOM)'nin tanımlarına göre şu şekilde gruplandırılmıştır (Peker,2014:9).

-Koleksiyonlarına göre müzeler; Genel Müzeler, Arkeoloji Müzeleri, Sanat Tarihi, Sanat Müzeleri, Tarih Müzeleri, Etnografya Müzeleri, Doğa Tarihi ve Jeoloji Müzeleri, Bilim Müzeleri, Planetaryumlar, Endüstri Müzeleri

-Bağlı oldukları kurumlara göre müzeler; Devlet Müzeleri, Belediye Müzeleri, Özel Müzeler, Askeri Müzeler

-Hizmet alanlarına göre müzeler; Bölge Müzeleri, Halk Müzeleri, Ekomüze 
-Hizmet ettikleri topluma yönelik müzeler; Uzmanlık Müzeleri, Çocuk Sanat ve Gençlik Müzeleri -Koleksiyonlarını sergiledikleri mekana göre müzeler; Sanal Müzeler, Müze Evler, Anıt Müzeler, Açık Hava Müzeleri

-Temalarına göre müzeler: Kişiyi Konu Alan Müzeler, Kent Müzeleri, Devrim Müzeleri

\section{MÜZE ve TEKNOLOJİ}

\subsection{Teknoloji ve Tanımlar}

Teknoloji, Eski Yunanca'da yapmak anlamına gelen "techner" sözcügü ile bilgi anlamına gelen "logos" sözcügünün kaynaşmasından türemiştir. Teknoloji sözcüguünün kökü olan teknik TDK' ya göre "bir sanat, bilim, bir meslek dalında kullanılan yöntemlerin hepsidir."; başka bir değişle üretmenin bilgisidir (<tdk.gov.tr> 11.11.2015). Yapma bilgisi anlamına gelen teknoloji ise bilginin toplumsallaşması, bir amaca ulaşma doğrultusunda örgütlenen bilgi, amaca ulaşmak için kullanılan araçlar topluluğu gibi çeşitli tanımlara sahiptir (Yenğin,2014:49).

Ampulün bulunmasıyla ortaya çıkan, serbest elektronları temel alan bir bilim dalı olan elektronik geçiş bir alana yayılmıştır. Elektroniğin bir parçası olan dijital kelime anlamı olarak "sayısal"dır. Sayısal değerler ve kombinasyonların elektronik aygıtlar üzerinden veriyi gösterir. Sanal, gerçekte var olmayan zihnide tasarlanan anlamına gelmektedir. Online ise eş anlamlısı olan "çevrimiçi" kavramıyla açıklanır (<whatis.techtarget.com>11.11.2015)

\subsection{Müze Hayatında Teknoloji ve Kullanımı}

Müzelerin kuruluşundan beri var olan teknolojik unsur güvenliktir. Güvenlik teknolojileri ister basit bir kilit sistemi ister biyometrik okuyucular olsun müze hayatının olmazsa olmazlarındandır. Alarmlar, hareket sensörleri, yangın detektörleri, kameralar olarak modern müze hayatına giren güvenlik teknolojikleri giderek hızlanan teknolojik gelişmelere seyirci kalmamış kimi zaman milyonları bulan eserleri korumak adına güvenlik teknolojilerine yaptıkları yatırımları artırmıştır.

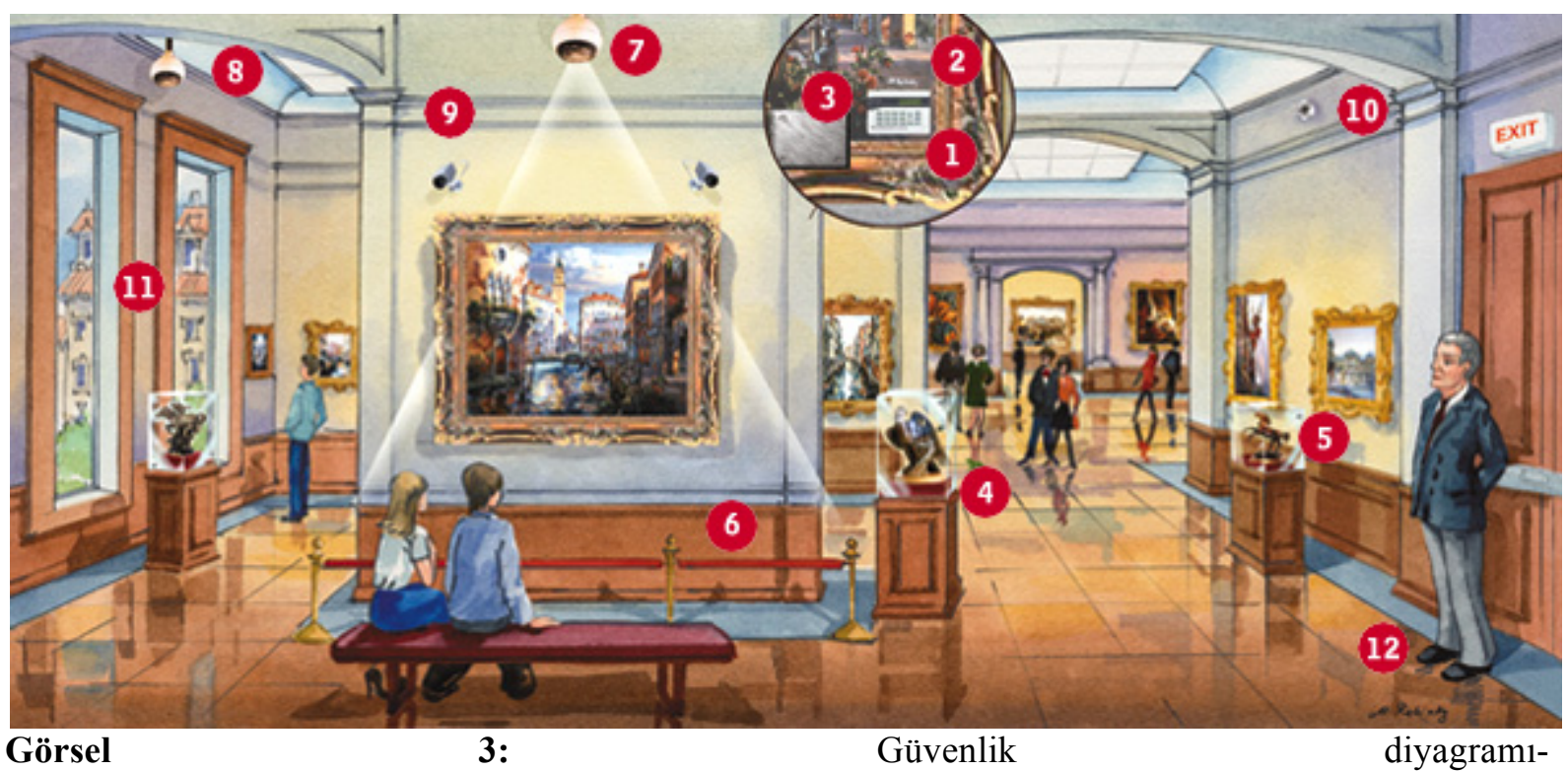

http://core0.staticworld.net/images/idge/imported/article/cso/2004/09/0904_art_

diagram-100255158-orig.jpg (13.11.2015) 


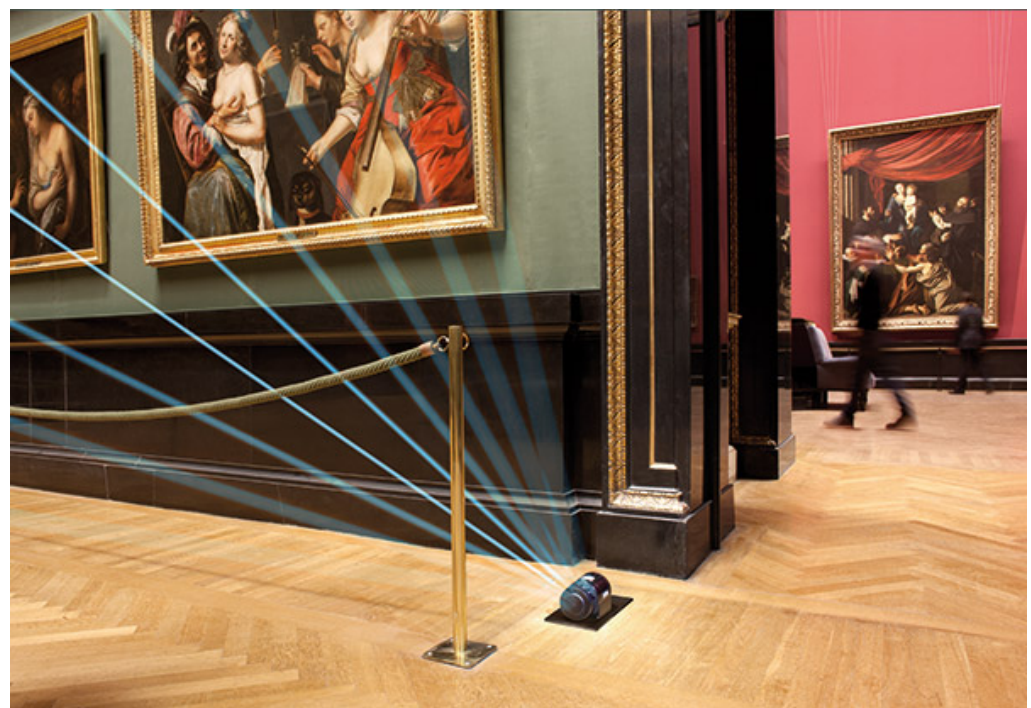

Görsel 4: Lazer detektör- http://www.sickinsight-online.com/laser-detectorsprotecting-art- treasures-at-kunsthistorisches-museum-in-vienna/ (13.11.2015)

Müze hayatına giren ilk teknolojik unsurlar güvenlikle ilgili olsa da, sandığımızdan eski olan ancak şuan hızla büyüyen unsur ise sergileme yöntemlerinde kullanılan teknolojidir. Kullandıkları teknolojiyle yeniden ilgi çekici hale gelen müzelerin "modernliği" teknolojiyi nasıl kullandıklarıyla ölçülür olmuş, son teknoloji ürünlerini müzelerin vazgeçilmez bir parçası haline getiren kurumlar öne çıkar olmuştur.

Günümüzdeki sergileme teknolojilerinin en ilkeli olarak kabul edebileceğimiz ancak dönemi için ciddi bir yenilik olan hareketli canlandırma mankenleridir. Müzelerde teknoloji kullanımına yumuşak bir geçiş sağlayan bu mankenler şuan oldukça basit görünen zaman ayarlı veya hareket sensörlü olan mekanik sistemlerdir. Bu mankenler odaya herhangi bir kişi girdiğinde oturup kalkma, yemek yeme, el sallama gibi basit hareketler yaparak müzenin temasını desteklemektedir. Kullanımı birçok yerel müzede devam etmektedir.

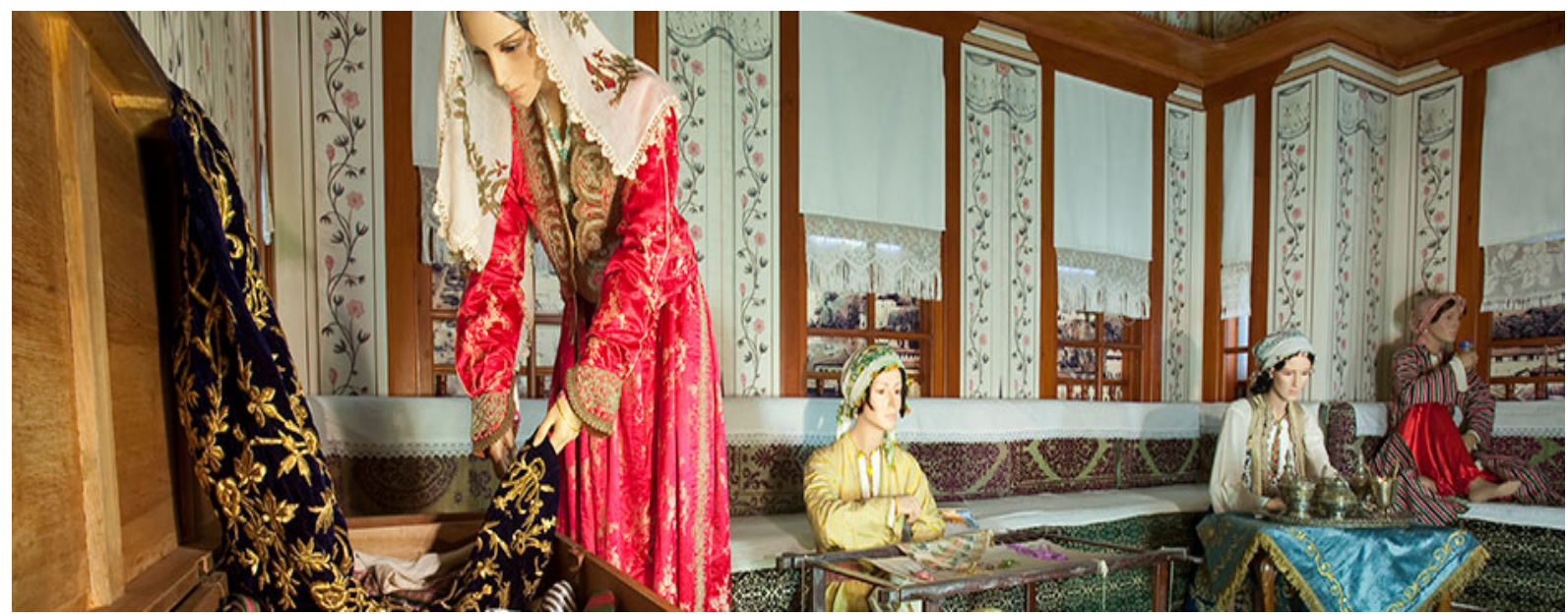

Görsel 5: Kaleiçi Müzesi, Antalya Evi -

http://www.kaleicimuzesi.com/index.php?page=antalyaevi2\&title=Geleneksel $\% 20$ Antalya $\% 2$ 0Evi\%20- \%20Antalya\%20Evi (13.11.2015)

Sergileme yöntemlerinden biri olarak kabul edilebilecek olan sesli rehberler de uzun zamanındır müze hayatında olan teknolojiler arasındadır. İlk başta yapılan kayıtları Mp3 tarzı cihazlarda dinleme imkanı sunan sesli rehberler, bu cihazların teknolojik olarak ilerlemesiyle görüntüye ve dil seçeneklerine kavuşmuştur. Hemen hemen her müzede bulunan sesli rehberlere, videolu anlatım seçeneğinin de eklenmesi ile bu imkan işitme engelliler içinde uygun hale getirilmiştir. 


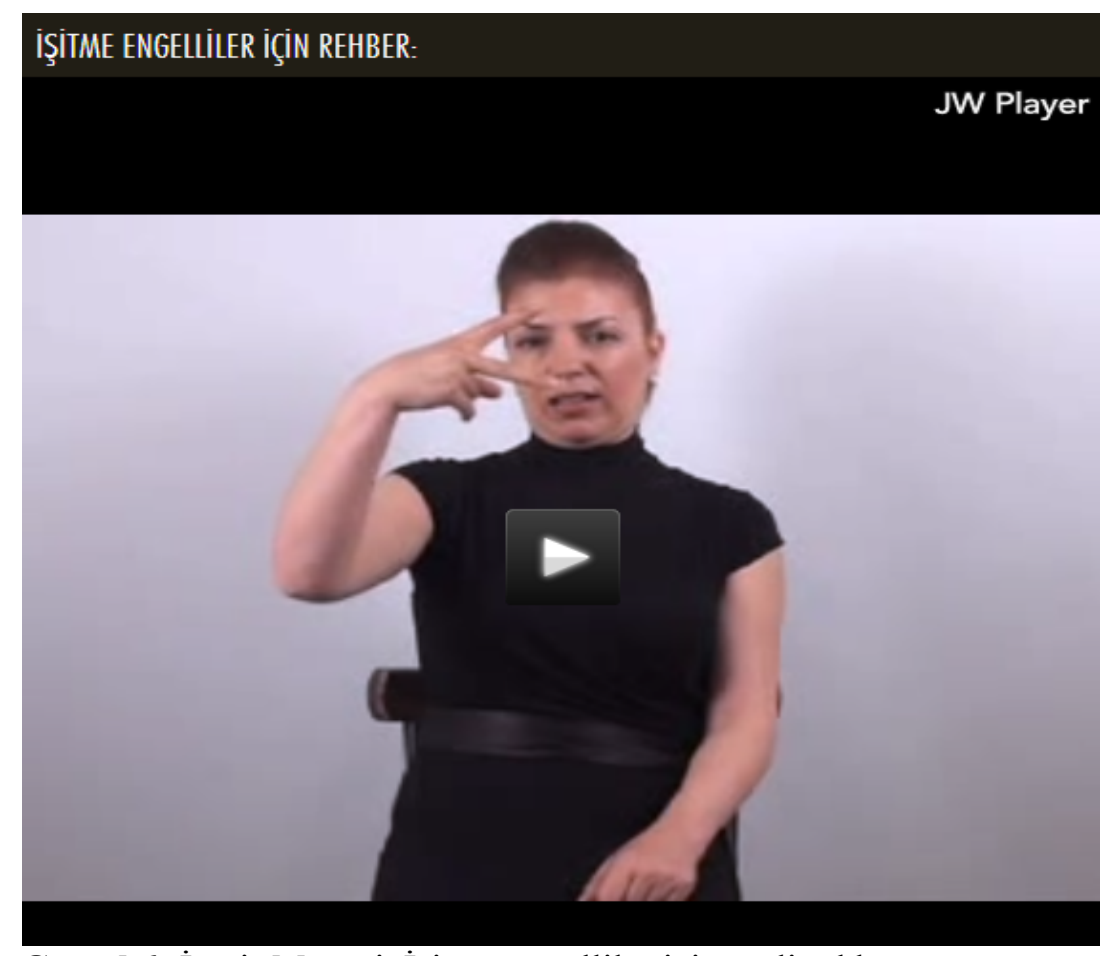

Görsel 6: İzmir Müzesi, İşitme engelliler için sesli rehber http://www.izmirmuzesi.gov.tr/e-muse-audio.aspx (13.11.2015)

Müzelerin en temel amaçlarından biri olan eğitim, günümüzde teknoloji odaklı bir hal almıştır. Öğrencilere sunulan film gösterimleri bunun çok küçük bir örneği olup, deneysel atölyelerden, müze içindeki kiosklarda oynanabilen öğretici oyunlara kadar bir çok yöntem bulunmaktadır. Bunun en önemli örneklerinden biri simülasyon teknolojisidir. Örneğin Rahmi Koç Müzesi'nde bulunan planetaryumda ziyaretçilere evren simülasyon yaratılmaktadır.

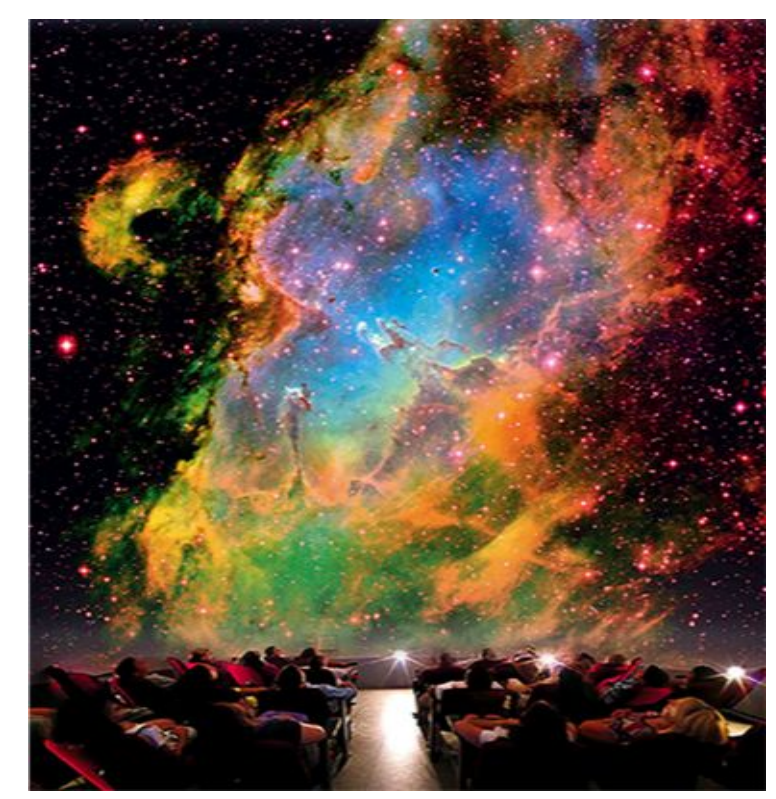

Görsel 7: Rahmi Koç Müzesi, Planetaryum

http://www.rmk-museum.org.tr/en/rmk_discovery_sphere.htm (13.11.2015) 
Telefonlara indirilen uygulamalarsa o müzeye özgü olabileceği gibi tüm müzeleri kapsayan ve başka özellikleri de olan ücretli veya ücretsiz uygulamalardır. Şuan beta aşamasına olan Müze Asist uygulaması buna bir örnektir (<www.muzeasist.com>13.11. 2015). Başka bir örnek ise Smithsonian Enstitüsü'nün başlattığı kullanımı oldukça kolay olan leaf snap uygulamasıdır. Merak edilen bitkinin fotoğrafı çekilip uygulamaya yükleniyor, bu şekilde o bitki hakkında bilgi alınabiliyor.

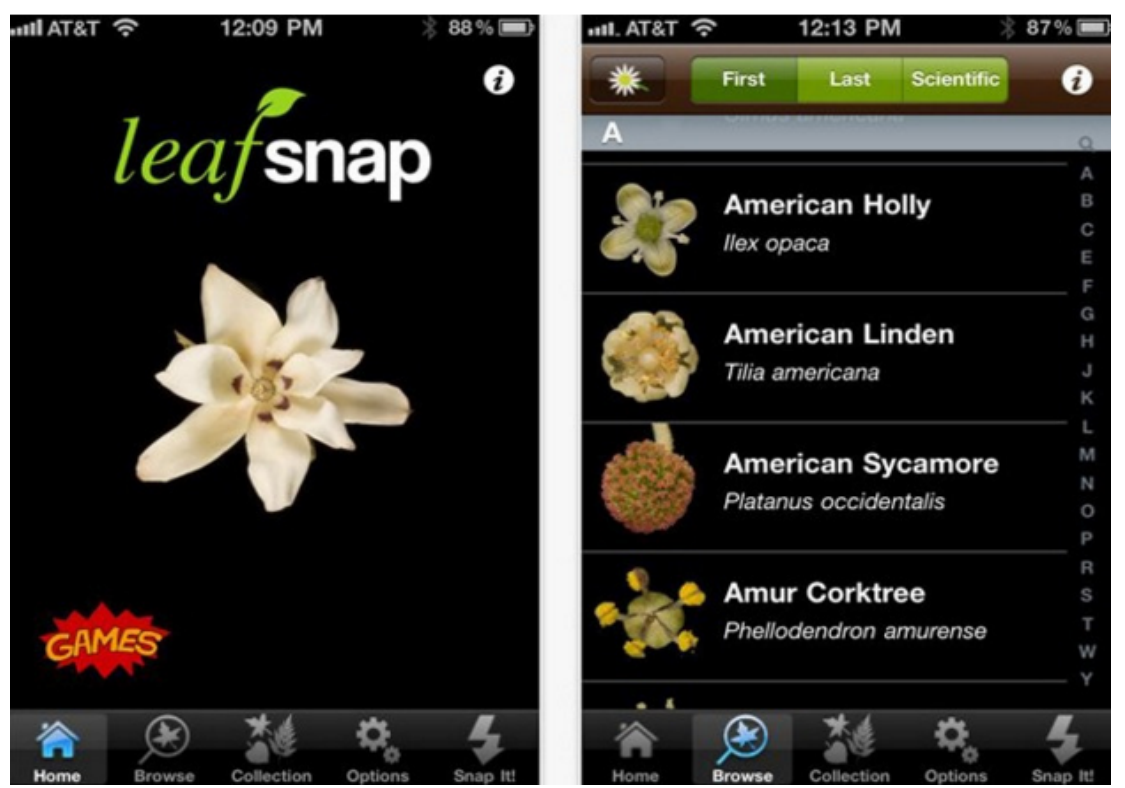

Görsel 8: Smithsonian Enstitüsü'nün leaf snap uygulamas1-

http://mashable.com/2011/09/14/high-tech-museums/\#9RhOZ8w8xiq5 (13.11.2015)

Bunun dışında müzelere konulan bilgilendirme ve öğretici amaçlı kiosklar, eserleri tanıtmaya yarayan dokunmatik masalar ve hareket sensörlü çeşitli uygulamalar bulunmaktadır. Müze hayatına giren yeni bir teknoloji ise tabletler ve telefon uygulamalarıdır. Barkot algılamasına sahip olan tabletler veya telefonlar, müzede sergilenen esere tutulduğunda o eser hakkında ayrıntılı yazılı bilgi vermekte, çevirisini yapmakta veya o esere benzer diğer eserleri bir slayt gösterisi olarak sunmaktadır.

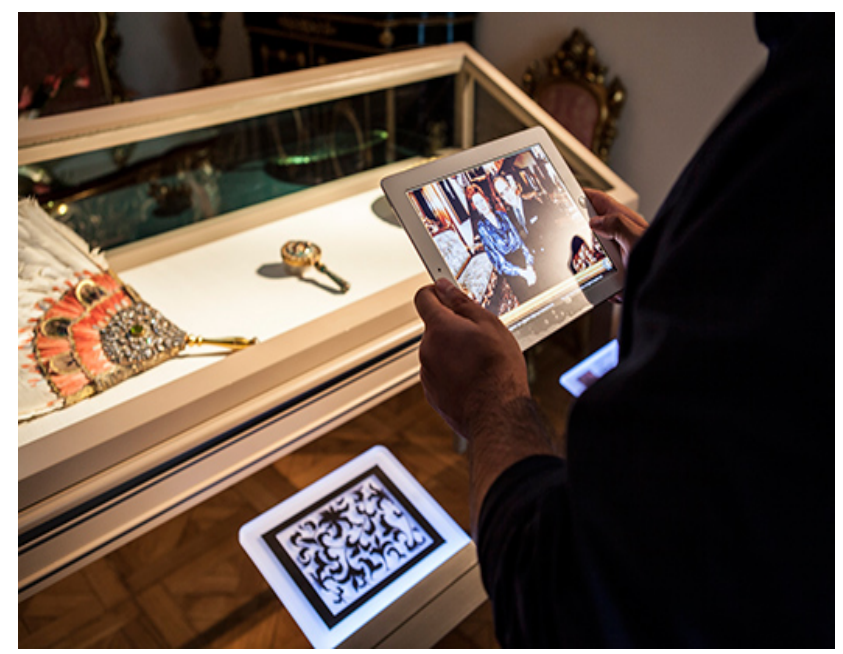

Görsel 9: Sakıp Sabancı Müzesi- http://www.log.com.tr/ sakip-sabanci-muzesine-ozel-dijital-muze-uygulamasi/

(13.11.2015)

$\mathrm{Bu}$ tabletler herhangi bir kimlik kartı karşılığında tüm ziyaretçilere teslim edilmekte, müze çıkışında da geri alınmaktadır. Sakıp Sabancı Müzesi, hat koleksiyonu için bu uygulamayı başlatmıştır. 
Müzelerde kullanılan bir başka teknoloji ise internet odaklı sistemlerdir. Kimi zaman arşiv kimi zaman katalog kimi zamansa reklam amaçlı kullanılan bu web siteler oldukça çeşitlidir. Dünyanın bir çok yerindeki müzede var olan $360^{\circ}$ sanal turlar (sanal gezinti), Türkiye'de Kültür Bakanlığı'nın kurduğu müzelerle sınırlı olmayan sistem tarafindan yapılmaktadır $(<$ www.kultur.gov.tr $>$ 13.11.2015).

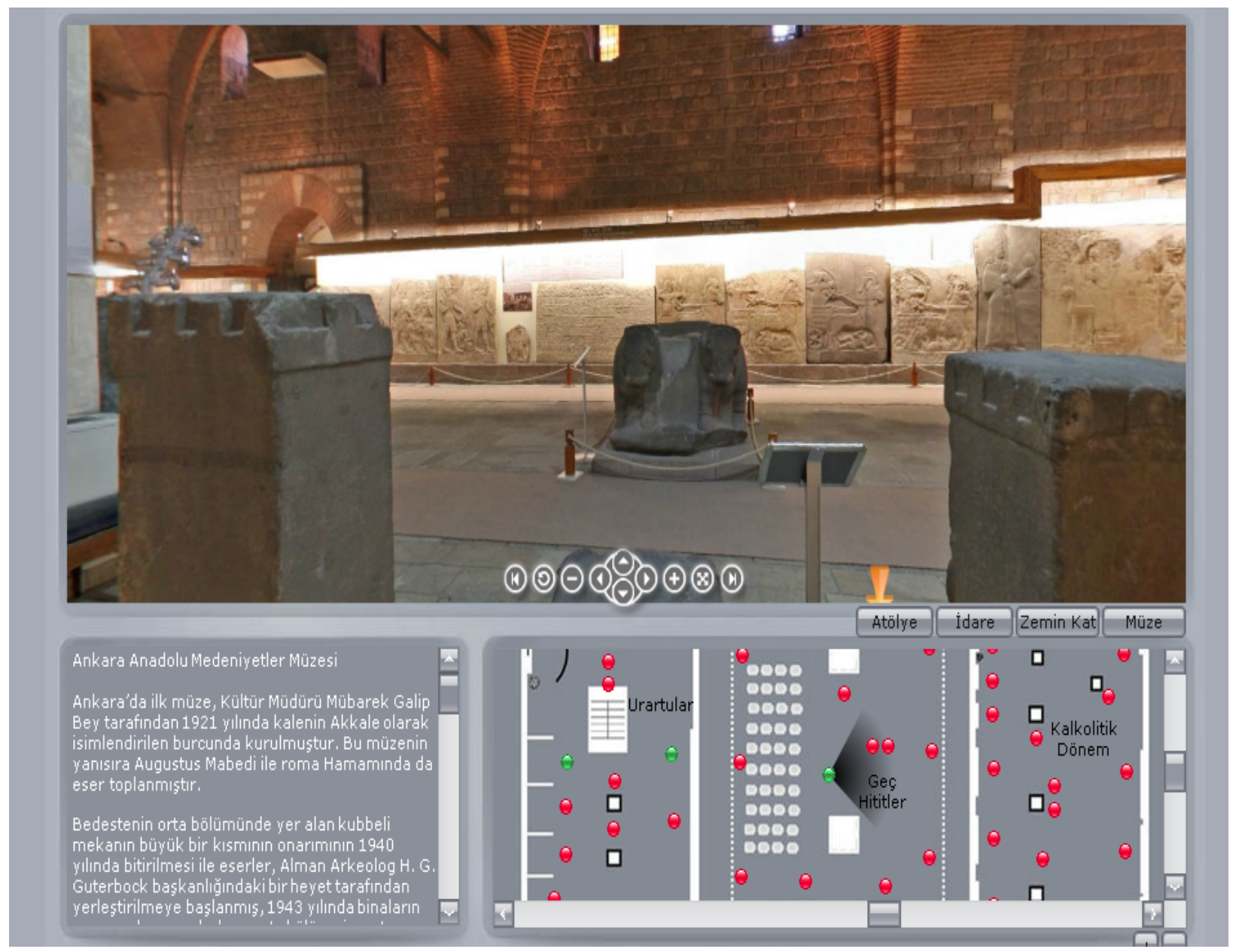

Görsel 10: Anadolu Medeniyetleri Müzesi, sanal gezintihttp://www.kultur.gov.tr/genel/SanalMuzeler/anadoluMM/index.html (13.11.2015)

Tanıtım amaçlı kullanılan sitelerse klasik reklam anlayışından farklı bir şekilde yapılmaktadır. $\mathrm{Bu}$ siteler genellikle müze ya da sergi koleksiyonlarının bir kısmını sitede yayınlayıp, açıklamadıkları için müzeye uğramaları yönünde tavsiyelerde bulunanlardır. Bunun yanında doğrudan kataloglarını web sitelerde ziyarete açan müzeler de mevcuttur. 


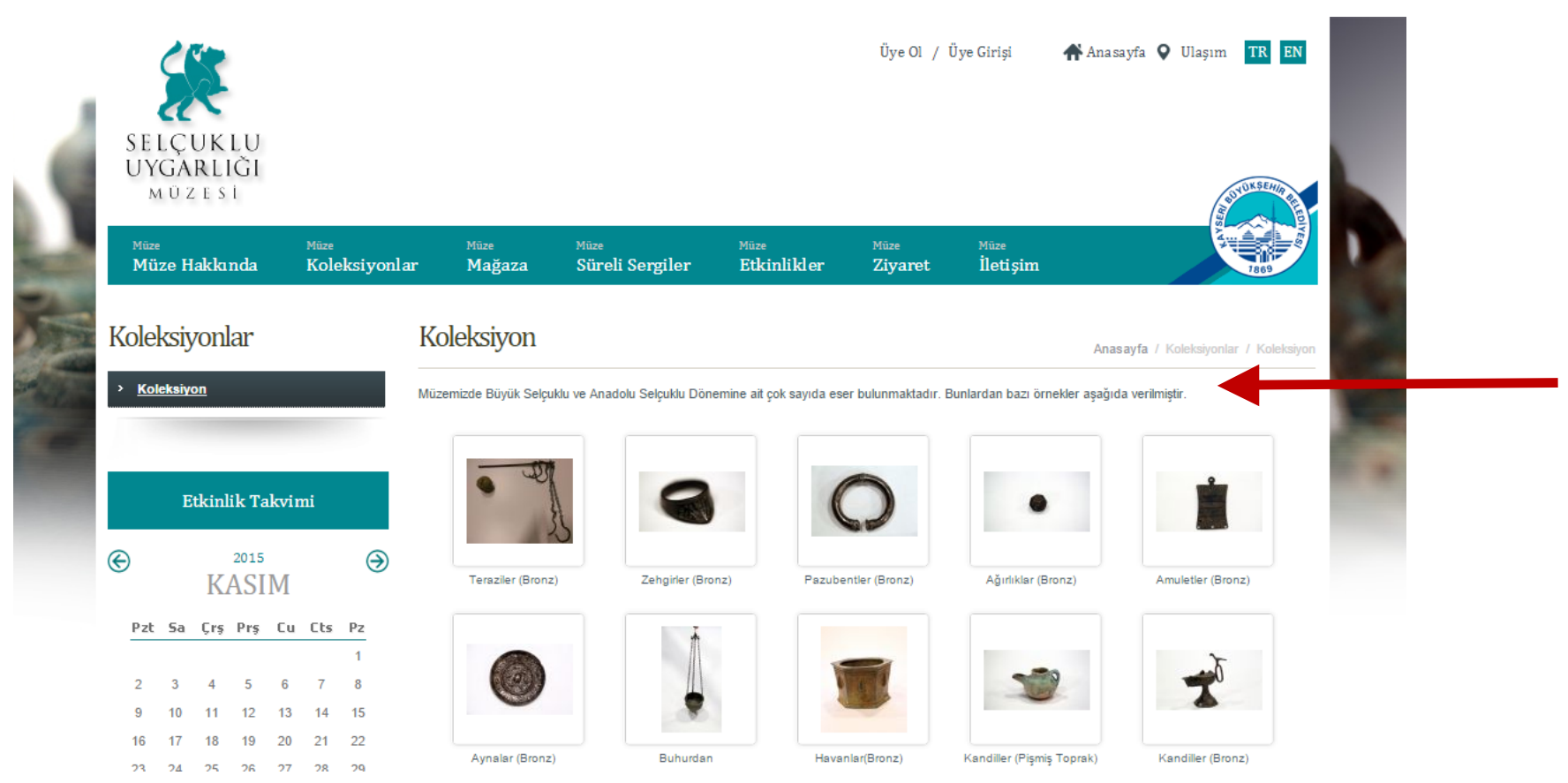

Görsel 11: Selçuklu Uygarlığı Müzesi Web Sitesi

$\mathrm{http}: / /$ www.selcuklumuzesi.com/ustmenu.asp?id=9\&euid=2\&sid=9 $(13.11 .2015)$

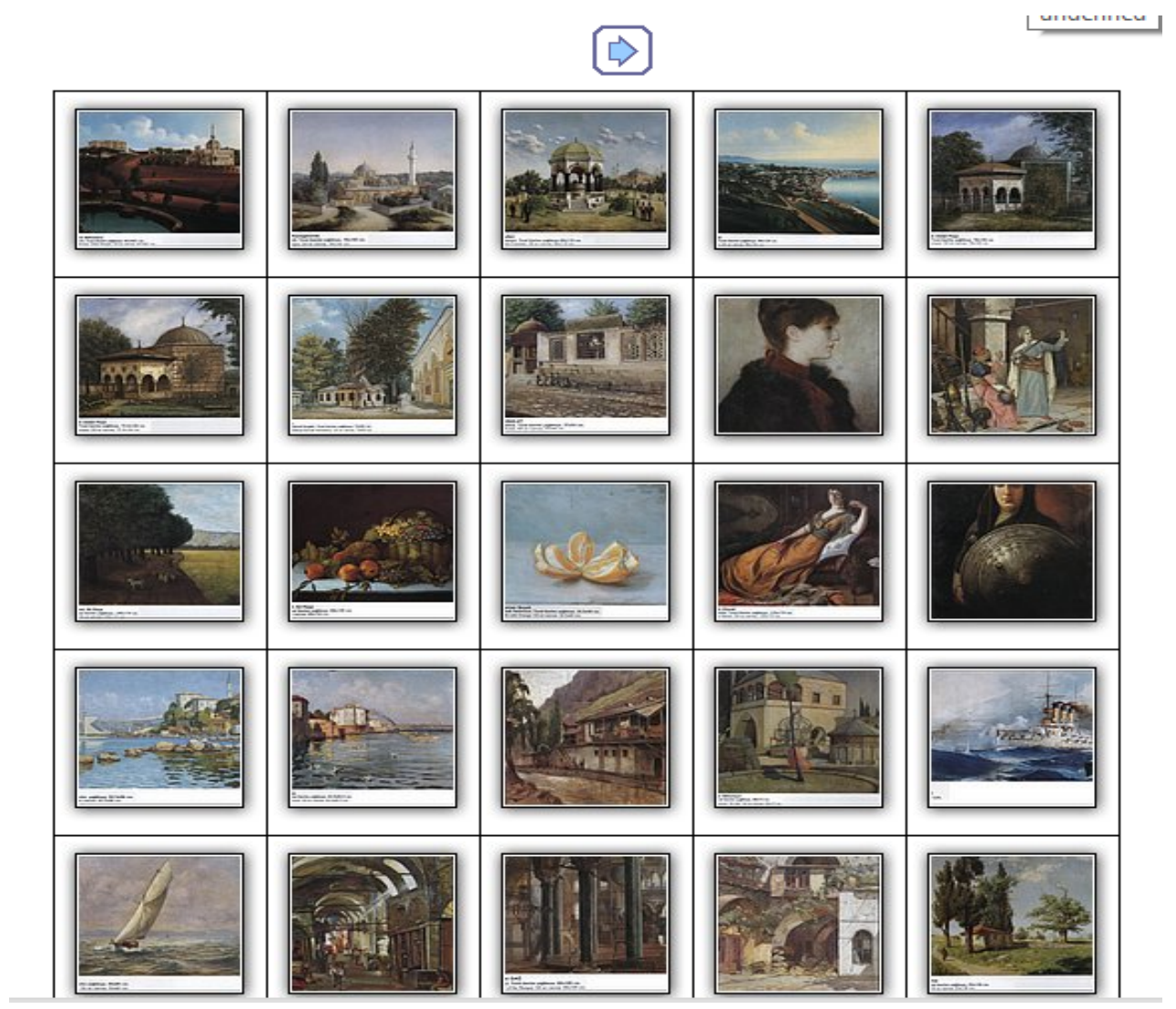

Görsel 12: Ankara Resim ve Heykel Müzesi, online katalog-

http://www.kultur.gov.tr/genel/SanalMuzeler/ResimHeykelMuzesi/katalog/index.html (13.11.2015)

Bazı müzeler ise internetin sunduğu imkanlardan yararlanarak, müze web sitelerinden ulaşılan eğitim siteleri kurmuş̧tur. Bu eğitimlerin büyük kısmı çocuklara yönelik şekilde tasarlanmış olan eğitici oyun 
siteleridir. Aynı web sitelerde ek olarak öğretmenlerinde eğitim planı hazırlamak yada eğitici materyal aramak üzere kullanabileceği $\quad$ veri tabanları bulunmaktadır $(<w w w . s m i t h s o n i a n e d u c a t i o n . o r g>13.11 .2015)$. Smithsonian Enstitüsü'nün Amerikan Tarihi Ulusal Müzesi'nin eğitim amaçlı kurduğu web sitede organlara ve uzuvlara ait görsel parçalar verilip, vücuttaki yerlerinin gösterilmesi isteniyor. Yanlış cevap verildiği takdirde doğru cevap daha büyük bir görselle gösteriliyor, ayrıca ayrıntılı bilgi veriliyor.

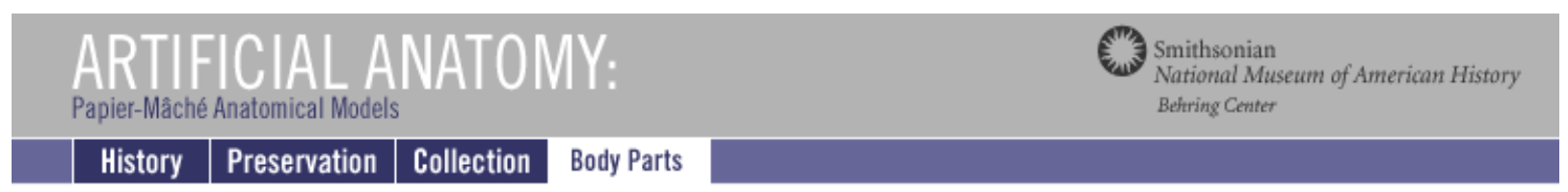

\section{BODY PARTS \\ 1. Inspect the mystery image on the left of your screen \\ 2. To find and select your answer, use your mouse to roll over Jerome's anatomy. \\ 3. Don't forget to look for additional answers by turning Jerome.}

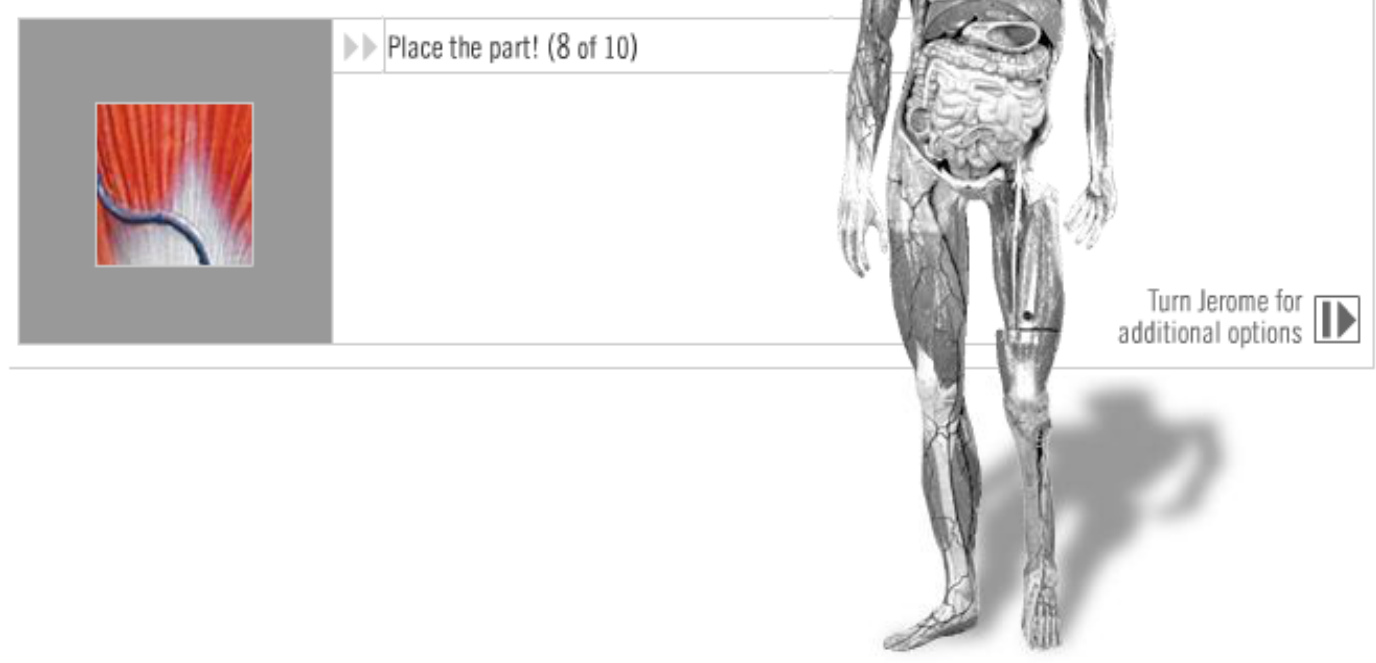

Contact | Resources | Credits and Copyright

Görsel 13: Smithsonian Enstitüsü, Yapay Anatomi

http://americanhistory.si.edu/anatomy/bodyparts/nma03_bodyparts.html (13.11.2015)

İnternet yaygın olarak kullanılmaya başladığı tarihlerden itibaren üzerinde dur duraksız çalışmalar yapılan bir başka web site uygulaması ise online müzelerdir. Sanal müzelerle karıştırılmaması gereken bu müzeler kimi zaman dijital müzeler de denmektedir. Kataloglarını internette yayınlayan müzelerden fark1 ise koleksiyonun görüntüsüyle birlikte koleksiyon hakkında bilginin de burada bulunmasıdır. Bu bakımdan bu tip müzeler araştırma yapmaya, kaynak olarak kullanılmaya uygundur. Sakıp Sabancı Müzesi, müzenin orijinal web sitesi dışında bu amaç doğrultusunda başka bir web sitesi yapmış ve dijital sözcüğünü kullanmayı seçmiş̧ir. Dijital Sakıp Sabancı Müzesi, fiziki müzenin tüm koleksiyonu barındıran ayrıntılı araştırmaya uygun bir online müzedir. 


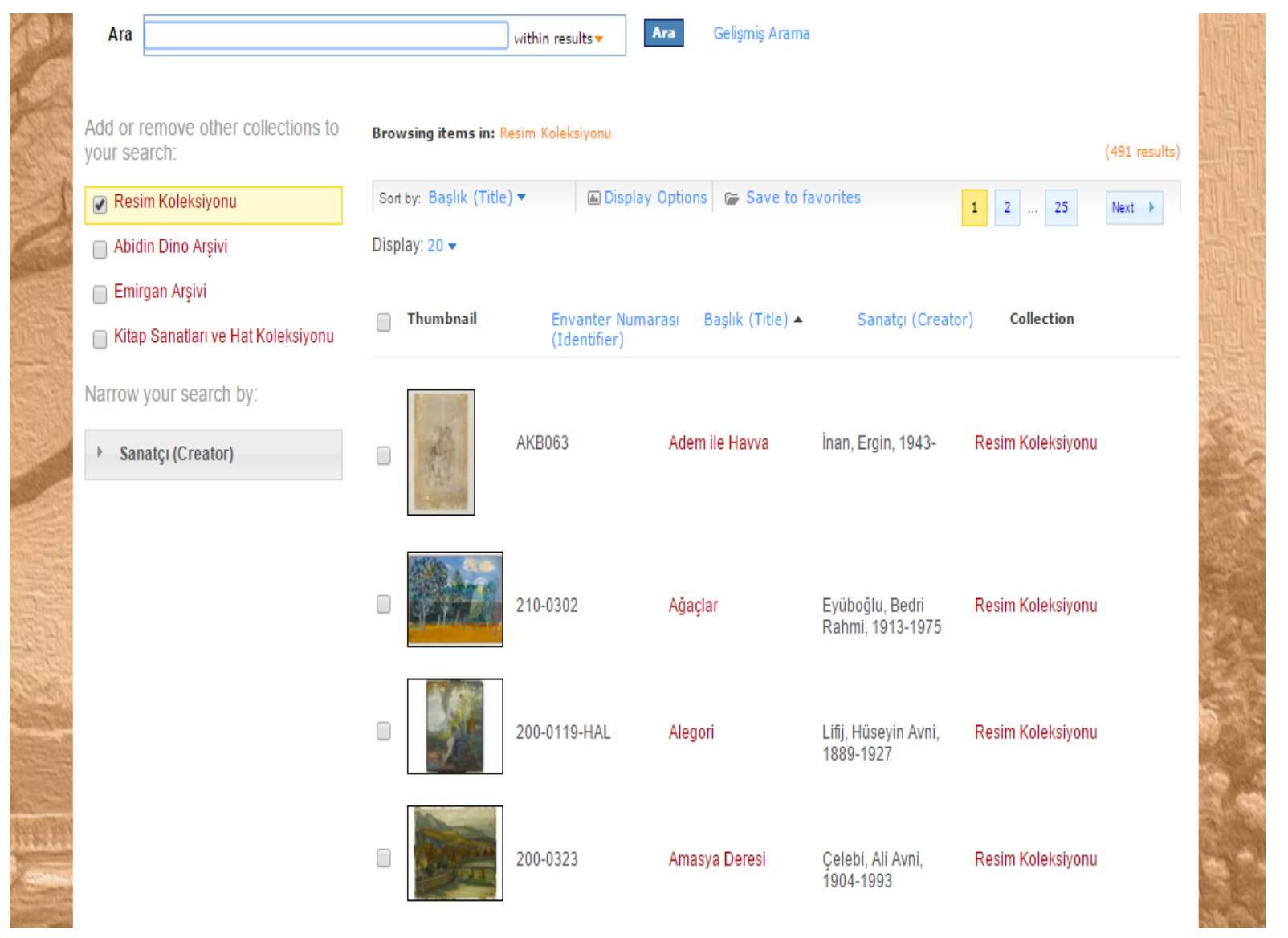

Görsel 14: Dijital Sakıp Sabancı Müzesi, Resim Koleksiyonu

http://www.digitalssm.org/cdm/search/collection/ResimKlksyn/field/all/mode/all/conn/and/or der/title/a d/asc (13.11.2015)

\section{ZAMANDAN ve MEKANDAN BAĞIMSIZ BİR MÜZE; SANAL MÜZE \\ 3.1. Sanal Müze Kavramı}

Sanal müze, ortak bir tanımı bulunmayan oldukça tartışmalı gelişmekte olan bir kavramdır. Sözlük anlamını inceleyecek olursak Britannica'nın yaptığı tanıma göre " Sanal Müze elektronik ortam aracılığıyla erişilebilinen sayısal olarak kaydedilmiş görüntüler, ses dosyaları, metin ve diğer tarihi, bilimsel ya da kültürel bilgi koleksiyonudur. Sanal müzenin gerçek objeleri barındıracağ 1 mekanı yoktur ve bu nedenle geleneksel müze tanımındaki süreklilik ve tekil nitelikten yoksundur. Aslında, birçok sanal müze geleneksel müzeler tarafindan desteklenmektedir ve varlıkları doğrudan geleneksel müzenin koleksiyonuna bağlıdır. Buna rağmen, elektronik bilgi ortamının sağladığı sayısız bağlantı imkanı ve çoklu ortam www pek çok kaynaktan derlenmiş ve bireysel kullanıcı tarafından biçimlenen sayısallaştırılmış sunumlara eğlence ve çalışma ortamı sunarlar. Bu tür sanal müzeler malzeme ve kaynak açısından kıyaslanmalı incelemeler yapmak için ve belli bir konuda araştırma yapmak için güçlü birer araçlar olabilirler." (<global.britannica.com>15.11.2015).

Uluslararası müze otoritesi ICOM'un tanımına göre ise sanal müze "Değişik medya imkanlarından faydalanılarak hazırlanmış sayısal nesneleri ve bunlara ait bilgileri barındıran, ziyaretçi ile iletişimin kesintisiz olması ve muhtelif erişim şekillerini karşılamak için alışıldık iletişim metotlarının ötesine geçen, dünya çapında erişimini olanaklı kılmak amacıyla fiziksel anlamda bir mekâna ihtiyaç duymayan müzelerdir." (Shweibenz, 1998:190).

Yine ICOM'un sınıflandırmasına göre sanal müzeler; broşür sanal müzeler, içeriksel sanal müzeler, eğitsel sanal müzeler ve sanal müzeler olarak dörde ayrılmıştır (Shweibenz,2004:3). Yine aynı makalede dijital müze, online müze, e-müze, web müze gibi terimler sanal müze ile eş anlamlı kabul 
edilmiştir. Sanal müze tanımıyla ilgili bu ana hatlar çizildikten sonra bir çok akademisyen bu açıklamaları doğru bulmamıştır. Tanımların yapıldığı yıllardan bu yana sanal yapılanmalar hakkındaki genel görüş de değişmiştir. Bu görüşlere bakacak olursak;

Çolak'a (2006) göre sanal müze, fiziksel olarak bir bütünlük içinde bulunmayan ancak benzer özellikler taşıyan sayısallaştırılmış koleksiyonu, yapay bir ortamda erişime sunarken, ziyaretçisine gerçek müze deneyiminde olan sınırları yıkmasına olanak veren uygulamadır (Peker,2014:25).

Varinlioğlu (2007) sanal müze ; var olan bilgilerin ve mekanın dijital (sayısal) ortama aktarılmasındansa, sadece sanallığın olanaklarıla ortaya çıarılabilecek bir müze oluşturmaktır (Peker,2014:25).

Resmi anlamda ortak bir tanım yapılmamış olsa da genel bir kanı olarak, internet üzerinde kurulmuş bir müzenin sanal müze olarak kabul edilebilmesi için taşıması gerektiğine inanılan bazı özellikler vardır. Bunlar; koleksiyonun sayısallaştırılarak küresel erişime açılması, dünyanın herhangi bir yerindeki ziyaretçiye her an sanal dolaşım imkanı sağlaması, uygulamaya özgü hizmetler ve bağlantılar sunması, arşiv ve kaynak niteliği taşıyan bilgilendirici özelliğiyle diğer müze web uygulamalarından ayrılmalı ve en önemlisi fiziksel bir mekana sahip olmamasıdır.

\subsection{Sanal Müze Tarihi ve Gelişimi}

1990'lı yıllarda internetin bireysel kullanımının yaygınlaşmasıyla müzeler de kurumsal web uygulamalarına geçmeye başlamıştır. Bu dönemin müze web siteleri ya da sanal müzeleri daha çok kütüphane ve arşiv niteliğinde düzenlenmiştir (<www.ibiblio.org $>15 / 11 / 2015)$.

Bahsedilen anlamda ilk sanal müzelerden biri Paris Web Müzesi'dir (Kubat,2012:20). LouvreWeb adıyla 1994'te kurulan müzenin adı telif hakları nedeniyle değiştirilmiştir. Bundan önceki müze ise 1993 tarihli Museum of Computer Art (MOCA)'dır (<moca.virtual.museum>15.11.2015). Bu dönemde bir çok sanatçı kişisel sanal müzelerini yapmaya başlamıştır. Singapurlu sanatçı Lin Hsin Hsin eserlerinin sanal ortamda toplayarak ilk kişisel sanal müzeyi kurmuştur (<www.lhham.com $>15.11 .2015)$. Özellikle taşınamayan kültürel miraslar veya somut olmayan kültürel miraslar sanal ortamda bir araya getirilerek sanal müzeler oluşturulmuştur.

Türkiye'de ise İstanbul Resim Heykel Müzesi için hazırlanan web sitesi (1993) bu kategorideki ilktir (Kubat,2012:20). 1990'ların başında saray koleksiyonunu dijital ortama aktarmayı amaçlayan Topkapı Sarayı Projesi ise sponsor ve teknolojik destek bulanamadığ için iptal edilmiştir (Barlas,2014:336). 1990'lı yılların ortasında Sabancı ailesine ait özel koleksiyon internet ortamına aktarıldı. Sabancı Resim ve Heykel Koleksiyonu, gerçek anlamda Türkiye'deki ilk sanal müzedir denilebilir. 2003 yılında Sakıp Sabancı Müzesi kurulduğunda, müzenin web sitesinin temeli olarak kullanıldı (Barlas,2014:336). Web sitesinin adı ise Dijital Sakıp Sabancı Müzesi olarak değiş̧tirildi. Benzer bir şekilde 1999'da ziyarete açılan Eczacıbaşı Sanal Müze, aile koleksiyonunu sanal ortama taşıdı. Türkiye'nin en geniş sanal sanat müzesi olan Eczacıbaşı Sanal Müze, 2004'te İstanbul Modern Sanat Müzesi kurulunca sanal müze arşivi İstanbul Modern web sitesine taşınmıştır (<www.sanalmuze.org > 15.11.2015). İlk kişisel sanal müze ise 2001'de Evin Sanat Galerisi tarafindan düzenlenen Nuri İyem'in koleksiyonerlerdeki eserlerini dijital ortama aktararak gerçekleştirdiği "Nuri İyem Resimleri Arşiv ve Belgeleme Projesi"dir (Kubat,2012:20). İlk dönem sanal müzeleri bu şekilde olup, dünya standartlarına ulaşılmamış olsa da zamanla sayıları artmıştır. Türkiye Sualtı Kültürel Mirası Sanal Müzesi, Sanal Mimarlık Müzesi, İstanbul Kadın Müzesi bunların arasında sayılabilir.

\subsection{Sanal Müzeye Eleştirel Yaklaşımlar}

Sanal müzelere karşı var olan olumsuz tutumlar aslında çok eskiye Walter Benjamin ve André Malraux arasındaki "sanat eserinin aurası" tartışmasına dayanmaktadır. 20. yüzyılda sanat eseri üretimine ve yeniden üretimine teknoloji de dahil olduğunda ortaya çıkan bu sorun, teknolojinin gelişmesiyle yeniden güncellik kazanmıştır (Torun,2015). Sanal müzeler için yapılan olumsuz eleştirilerin en başında, tıpkı Walter Benjamin'in söylediği gibi, eserin birebir görüldüğünde yarattığı etkiyi duygusal yoğunluğu yaratamıyor olması gelir. Sanat eserini ya da herhangi bir müze materyalini yakından, aracı kullanmadan, çıplak gözle görmek isteyen müze ziyaretçiler, sanal müzeler gezintilerini ve diğer her türlü internet üzerinden yapılaşmayı sanatın metalaşması olarak 
algılamakta ve ayrıca araya giren teknolojik aygıtlar nedeniyle sanatçıyla bağlarının kesildiğini düşünmektedirler.

Fiziki müze ziyaretlerinin önemli bir kısmının mimariyle olan doğrudan ilişkilidir, mimari yapıların insan üzerinde bilinen bir psikolojik etkisi vardır. Yapıların büyüklüğünden ve kurumun otoritesinden kaynaklanan saygının insanların sesiz olmaya itmesi gibi. Sanal müze ziyaretlerinde bu psikolojik etkiyi bulamayan ziyaretçi sayg1 duymamakta ve eserden aynı ölçüde etkilenmemektedir (Barlas,2014:330).

Sanal müzeler için çok sayıda olumlu eleştiriler de yapılmaktadır. Bu eleştirilerin büyük kısmı sanal müzenin taşıması gereken özelliklerden doğmaktadır. Her gün her saat dünyanın her yerinden ziyaret edilebiliyor olması sanal müzelerin en baş özelliği ve olumlu eleştiri sebebidir. Dünya mirasını koruma ve herkese ulaştırabilme özelliği taşıması, doğru ve güvenilir bilgi kaynakları olması, fiziki müze deneyiminin aksine herhangi bir sınıra sahip olmaması gibi olumlu eleştiriler yapılmaktadır. Bunun dıșında sanal müzeleri, fiziksel müzelerden avantajlı kılan bir özellikte güncellikleri ve yenilenebilirlikleridir. Yeni bir buluş karşısında fiziki müzelerin aksine içeriklerini son derece hızlı bir biçimde yenileyerek güncel kalabilirler (Peker,2014:16). Başka bir olumlu yaklaşım da sanal müzelerin kendine özgü bir sosyal topluluk oluşturmuş olmasıdır. Bazı sanal müzelerde ziyaretçilerin yorum bırakabileceği alanlar mevcuttur, fiziki müze koşulların birbirini tanımayan insanlar eser hakkında görüş paylaşımında bulunmasa da sanal müzelerde bu imkanın mevcut olması yeni bir sosyalleşme alanı yaratmıştır (Barlas,2014:333).

\section{SANAL MÜZE ÖRNEĞİ OLARAK: IRAK SANAL MÜZESİ "THE VIRTUAL MUSEUM OF IRAQ"}

4.1. Örneklemin Seçilme Nedeni

Irak Sanal Müzesi'nin seçilme nedenleri başında sanal müzelerin sahip olması gereken özellikleri taşıyor olması vardır. Koleksiyon sayısal olarak sanallaştırılmış, 7/24 dünyanın her yerinden ziyaretçilere açılmış, eserler hakkında ayrıntılı bilgilendirmeler yapılmış, sistem çeşitli araçlarla desteklenmiştir ve en önemlisi Irak Sanal Müzesi herhangi bir fiziki müzeye bağlı değildir. Hali hazırda kendine ait bir web sitesi olan Ulusal Irak Müzesi, Irak Sanal Müzesi'ne esin kaynağ olmuştur, ancak herhangi bir şekilde koleksiyonları bağlı değildir. 07-12 Nisan 2003'te yağmalanan Ulusal Irak Müzesi, bu trafik olay sonrası kapatılmış bugüne kadar sadece üç etkinlik için halka kapılarını açmıştır. 23 Şubat 2009'dan beri sadece VIP turlar ve okul grupları tarafından ziyaret edilebilen bu müze de aslında bir bakıma sanallaşmıştır (<www.iraqmuseum.org > 15.11.2015).

Doğa ve bölge halkları tarafından yok olma tehlikesiyle karşı karşıya bırakılan Mezopotamya Uygarlıkları Tarihi'nin korunması, arşivlenmesi ve tüm insanlığa aktarılabilmesi adına yapılan bu çalışmanın gösterdiği duyarlılık ve emek göz önüne alınarak örneklem olarak Irak Sanal Müzesi seçilmiştir.

\subsection{Müzenin Manifestosu}

İtalyan Dışişleri Bakanlığı tarafindan desteklenen ve İtalya Ulusal Araştırma Konseyi tarafindan gerçekleştirilen bilimsel ve kültürel ölçekte bir sanal müzedir. Projenin amacı; dünyanın en önemli müzelerinden biri olan Irak Ulusal Müzesi'nin arkeolojik, tarihi ve sanatsal mirasını, site aracılı̆̆ıyla halka ulaştırmaktır. Irak Sanal Müzesi'nin orijinal müzenin mimarisini, yerleşiminin taklit etmek ya da yenisini yapmak gibi bir amacı yoktur. Aynı şekilde orijinal müzede bulunan objelerin kapsamlı bilgi bankasına sahip olduğunu iddia etmez. Irak Sanal Müzesi; paha biçilmez tarihi ve arkeolojik mirasın bilgisine, herhangi bir koruma projesi için gerekli temeli oluşturacak şekilde somut katkıda bulunmayı ve aynı zamanda uluslararası seviyede bir iletişim projeksiyonu olmayı hedefler $(<\mathrm{http}: / /$ www.virtualmuseumiraq.cnr.it $>15.11 .2015)$.

\subsection{Müzenin İncelenmesi}

Irak Sanal Müzesi'ne www.virtualmuseumiraq.cnr.it linki üzerinden ulaştığımızda karşımıza üç dil seçeneği çıkmaktadır. Bu diller sırasıyla İtalyanca, İngilizce ve Arapça'dır. Yazı karakteri olarak Arial kullanılmıştır, puntolar ise değişmektedir. Sayfanın arka fonu olan Bağdat Haritası'nın üzerindeki siyah-gri blokta antik bir mask ve dil seçenekli giriş butonları yer almaktadır. Sürekli yenilenmekte 
olan bir site olduğu için tüm medyaların açılması için bazı uygulamalar gerekmektedir, bunun bilgisi butonların yanındaki kutucuklarda uzantılarıyla birlikte verilmiştir.

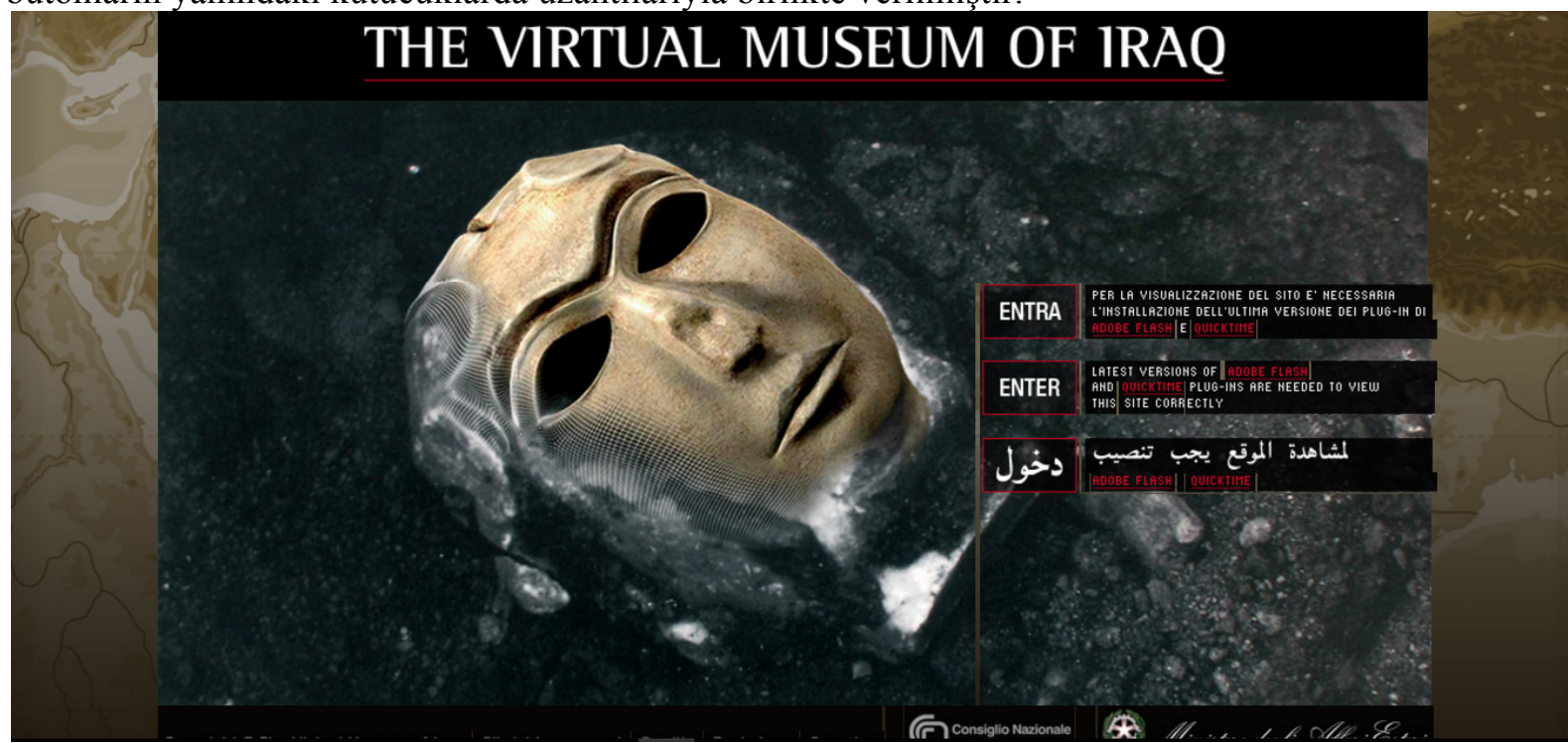

Görsel 15: Irak Sanal Müzesi giriș sayfası - http://www.virtualmuseumiraq.cnr.it/homeENG.htm $(16.11 .2015)$

Siteye İngilizce butonu üzerinden giriş yaptığımızda karşımıza aynı fonlar üzerinde yer alan 1 dakika 39 saniyelik bir video çıkmaktadır. Müzik eşliğinde sunulan bu videoda öncelikle harita üzerinde Bağdat gösterilmekte giderek yakınlaşan bir şehir haritasıyla Irak Müzesi'nin fiziki yerleşimine gelinmekte burada Irak Müzesi'nin tarihi kısaca anlatılmaktadır. Ardından müzenin fiziki yapısı bir canlandırma ile gösterilmekte buradan da müzenin içine sanal olarak girilmektedir.

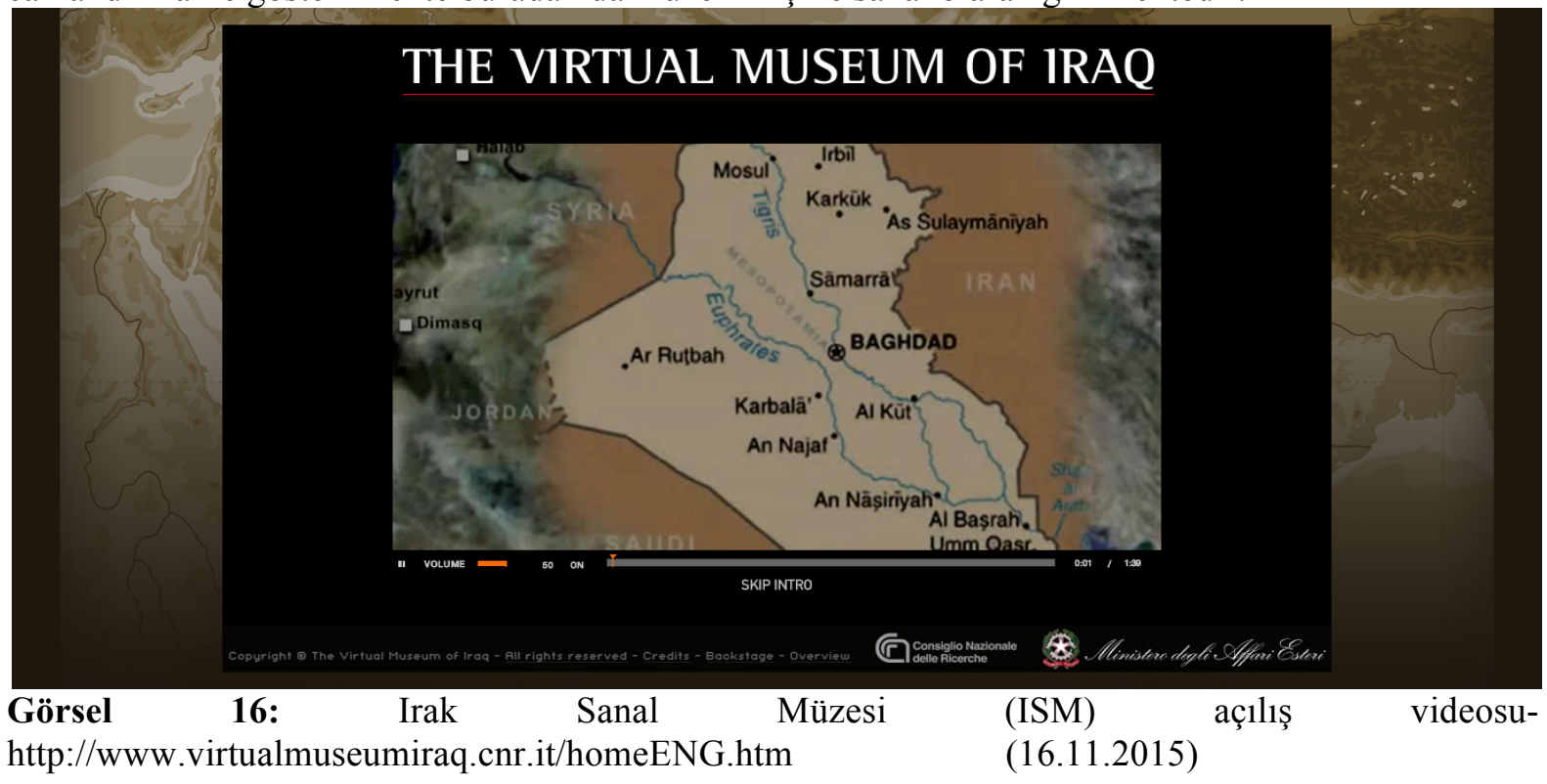

Müzenin k1sa tarihini anlatan videonun sonunda Mezopotamya'da doğmuş sekiz medeniyete ait tematik hollerin girişleri kronolojik olarak karşımıza çıkmaktadır. Her holde dönemi temsil eden objeler ve bunlarla ilgi farklı formatta olan bilgilendirme yazıları, üç boyutlu modeller, kısa videolar, animasyon filmleri, haritalar, uydu görüntüleri ve planlar bulunmaktadır. Irak Sanal Müzesi'nde tam olarak yetmiş obje, kırk 3D model, yüzden fazla görsel, yirmi iki film ve on sekiz arkeolojik bölge vardır. Müzeyi baştan aşağı dolaşmak yaklaşık altı saat sürmektedir. 


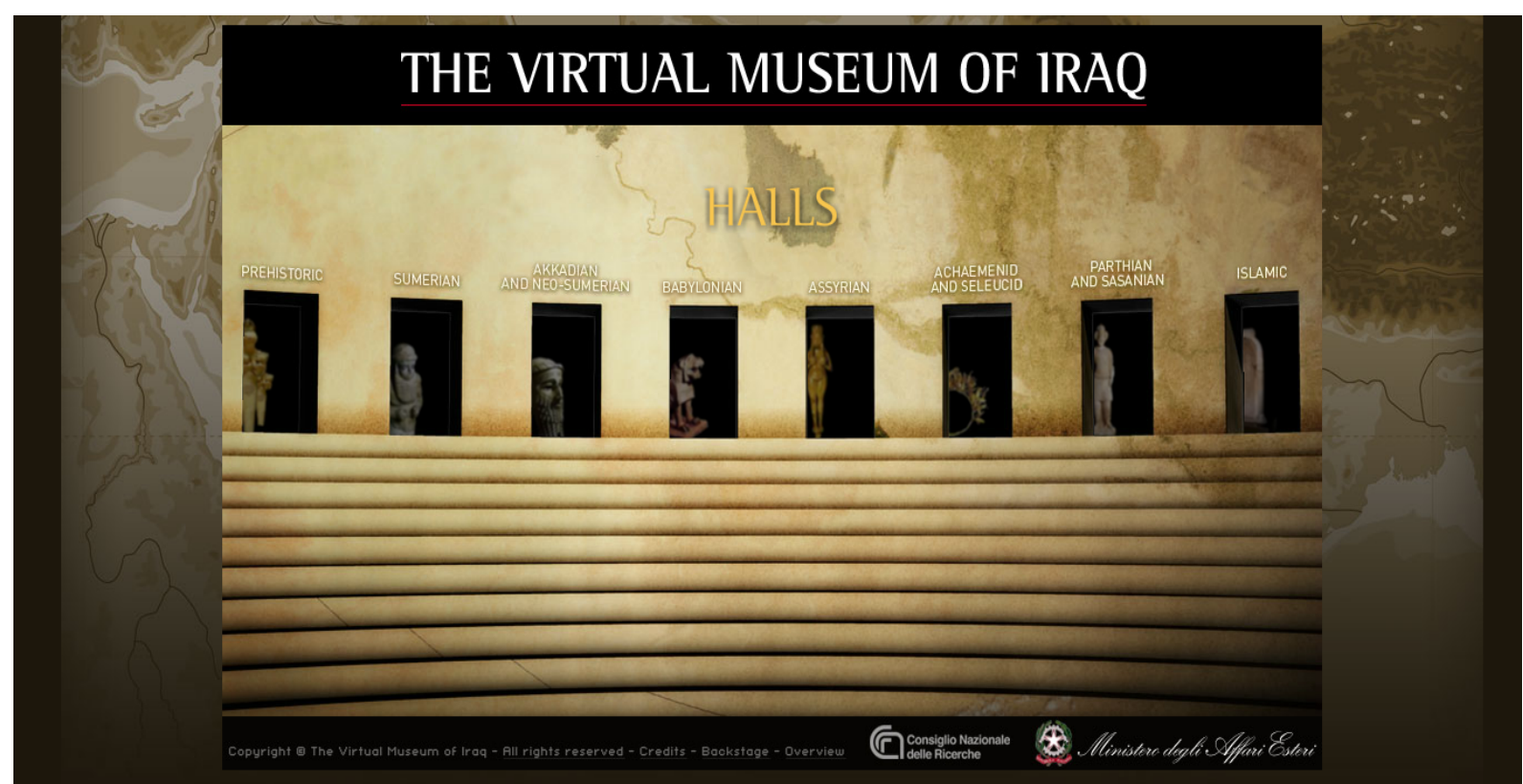

Görsel 17: ISM,Uygarlık Hollerine giriş - http://www.virtualmuseumiraq.cnr.it/homeENG.htm $(16.11 .2015)$

Videonun penceresi kapandıktan sonra farklı bir açıdan verilen hol girişleri, video sekmesi kapatıldıktan sonra dik bir açıyla verilmektedir. Sekiz tematik holden herhangi bir müzik eşliğinde seçilebilir. Tekrar bu noktaya dönülmek istendiğinde sol köşedeki butonla tıklanmalıdır.

Dördüncü sırada olan Babil Holü seçilerek bu uygarlığa ait sergi salonuna girilmiştir. Sergileme o dönem için uygun bulunan bir müzik eşliğinde yapılmaktadır. İstendiği takdirde müzik sağ üst köşedeki butondan kapatılabilmektedir. Salonda sergilenen her bir objenin üstüne 1şık tutulmuştur.

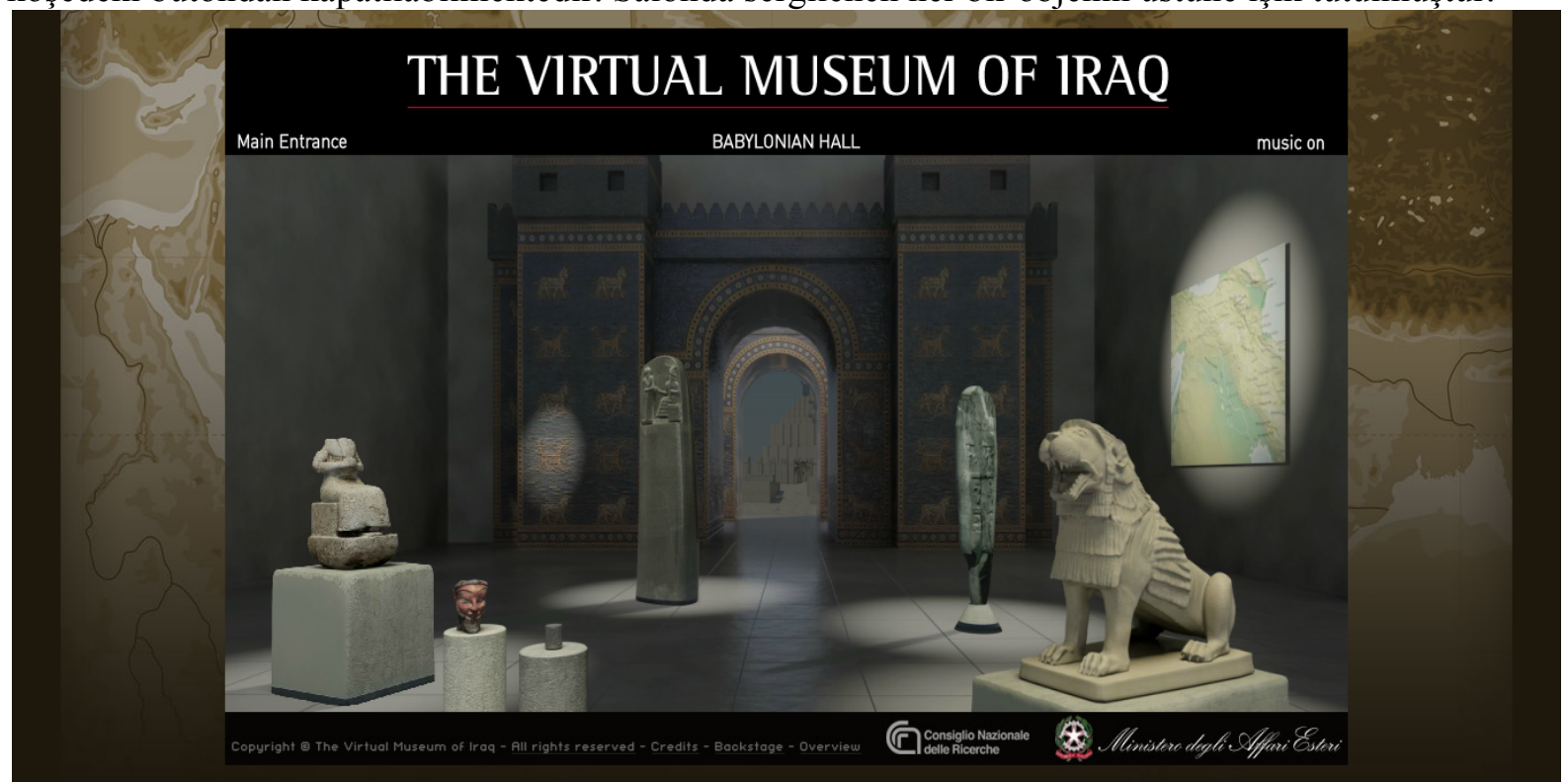

Görsel 18: ISM, Babil Uygarlı̆g1 ana hol - http://www.virtualmuseumiraq.cnr.it/homeENG.htm (16.11.2015)

Babil Salonu'nda dönemin devletine ait bir haritada sergilenmiştir. Bu harita üzerinden coğrafi ve tarihi bilgiler aktarılmaktadır. Haritanın üzerine tıkladığımızda karşımıza iki seçenek çıkmaktadır. Bunlardan harita incelemesini seçtiğimizde Sippar ve Babylon adlı şehirlerin yerleşim yerini ve planlarını incelenebilmektedir. Bu alandan ayrılmak istediğimizde sağ köşede bulunan çarpı işaretiyle bir önceki görsele dönerek Babil Holü'ne ulaşabilinmektedir. Harita üzerinden yapabileceğimiz ikinci seçenek ise bölgenin tarihini kronoloji cetveli üzerinden incelemektir. 


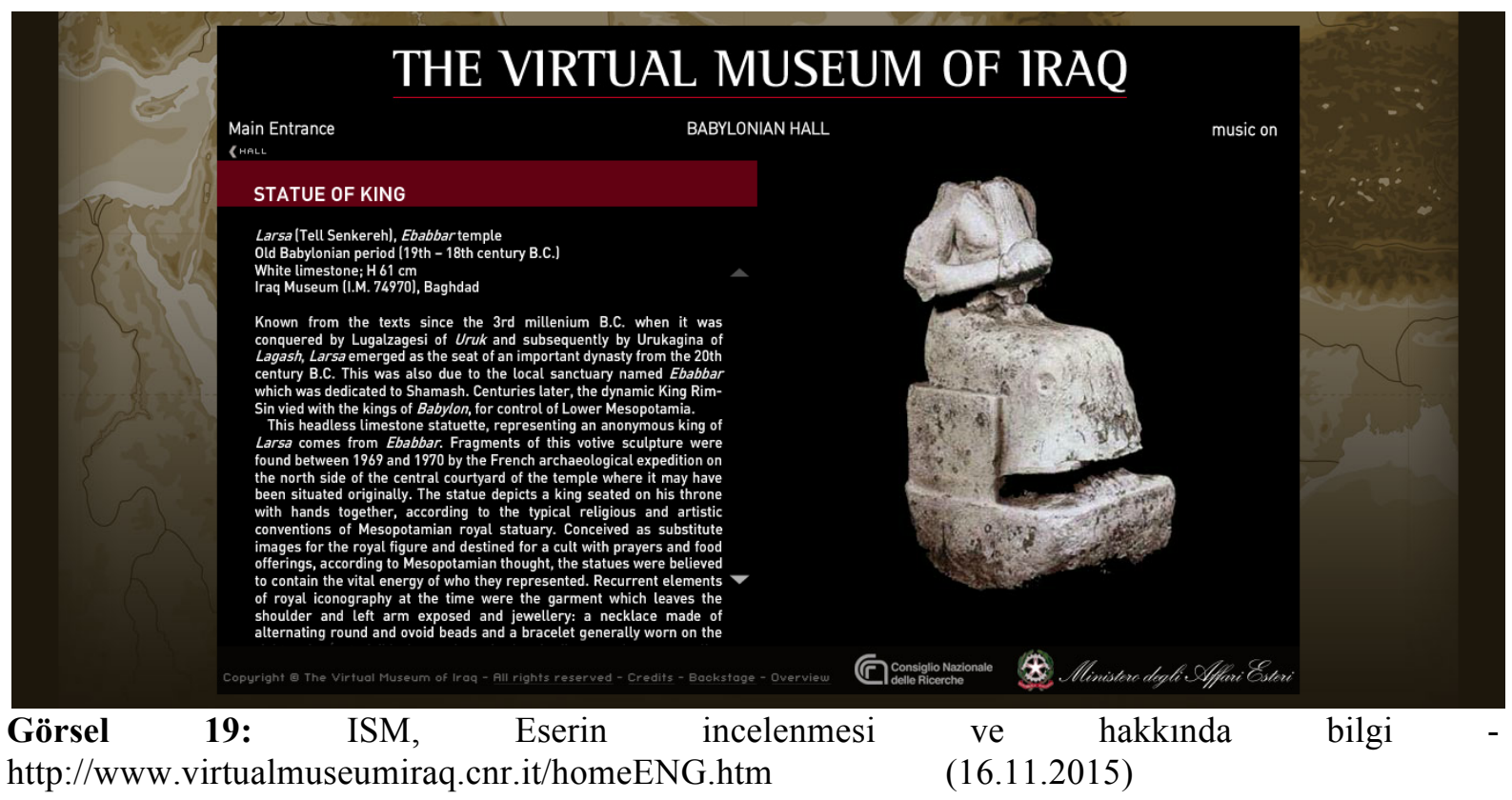

Hole döndüğ̈̈müzde var olan altı heykelden herhangi birini inceleyebilirsiniz. Heykellerin üzerine tıklandığında iki ya da üç seçenek çıkmaktadır. İlk seçenek objeler hakkında ayrıntılı bilgi veren "description" butonudur. İkinci seçenek ise teknik sebeplerle ya da uygulama eksikliğiyle her heykel için açılamayan "explore" seçeneğidir. Bu kısım daha çok ayrıntılı görsellerden oluşmaktadır. Bazı eserler içinse üçüncü bir seçenek olan "video" butonu mevcuttur.

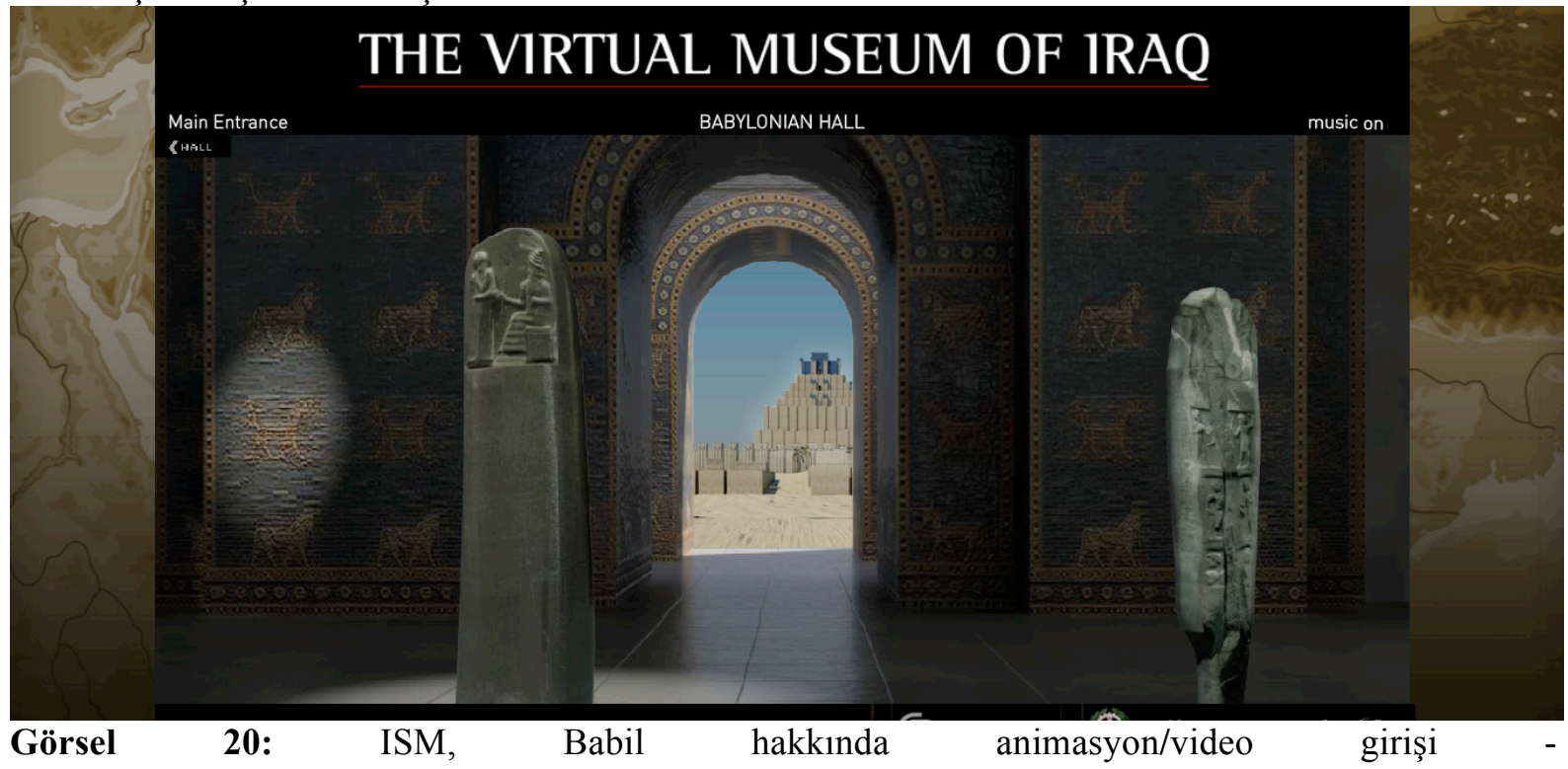

http://www.virtualmuseumiraq.cnr.it/homeENG.htm (25.12.2015)

$\mathrm{Bu}$ incelemeler yapıldıktan son salona dönmek için sol köşede bulunan "hall" butonunu kullanmak yeterlidir. Holde altı heykelin dışında koridora açılan "İştar Kapısı (Isthar Gate)" hakkında bilgi verilmekte, kapının üzerinde bulunan resimlerle ilgili fotoğraflar bulunmakta ve konu video ile desteklenmektedir. "İştar Kapısı" sergilemeyi farklı bir alana taşıyan bir geçit olarak kullanılmıştır. 


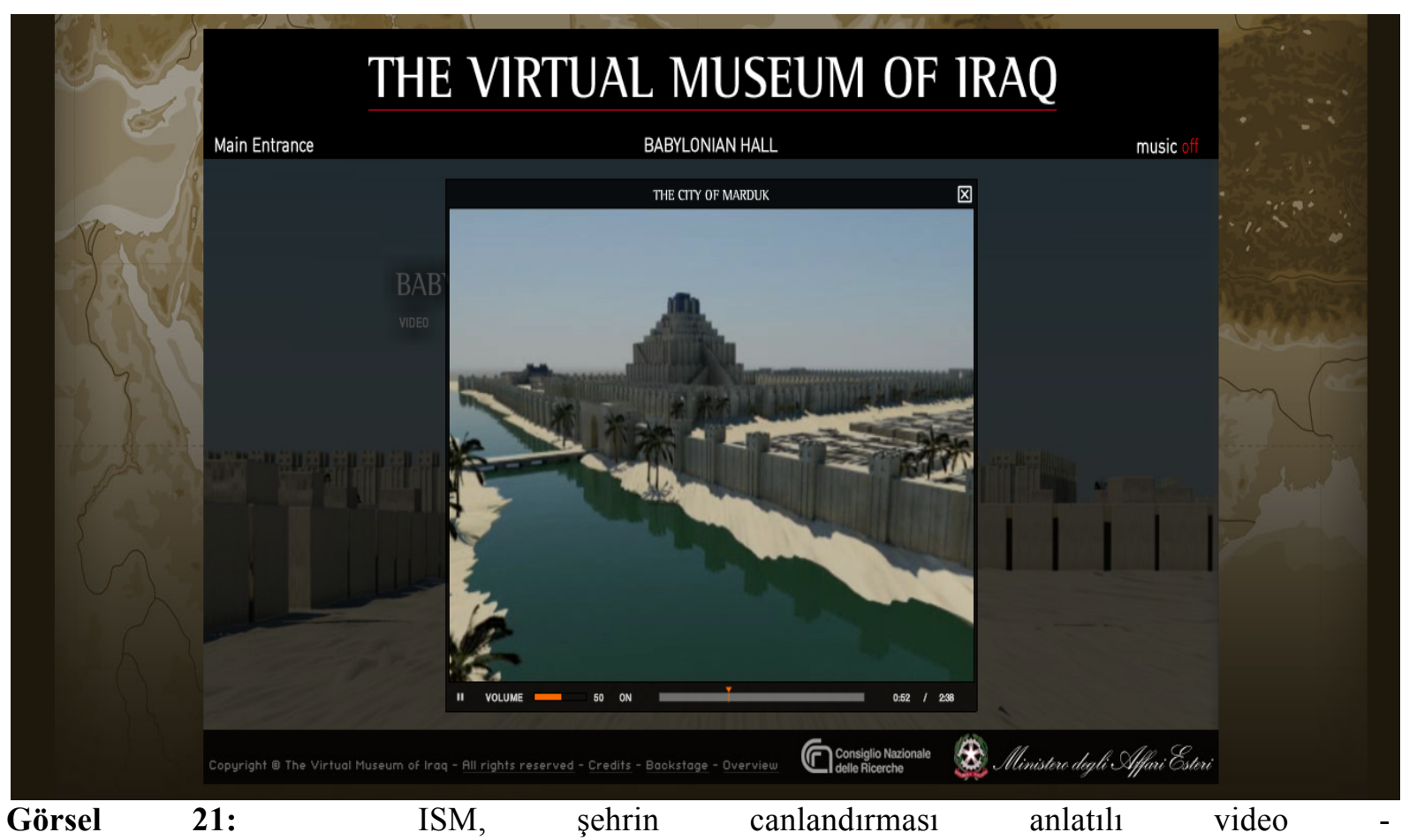

http://www.virtualmuseumiraq.cnr.it/homeENG.htm (16.11.2015)

Salonun sonundaki "İştar Kapısı"ndan geçtiğimizde tarihte de olduğu gibi Babil şehrine çıkmaktadır. Şehir, animasyonla canlandırılmıştır ve kalıntıların fotoğraflarıyla desteklenmiştir. Şehrin kuruluşunu ve tarihini anlatan video 2 dakika 38 saniye sürmektedir. Şehrin mimarisinden halkın inanışına kadar farklı bilgiler aktaran bu video belgesel niteliği taşımaktadır.

Babil Holü'ndeki gezimiz sonlandığında sol üst köşedeki "Main Entrance" butonundan ana girişe dönebilmektedir. Ana girişte gelindiğinde geriye kalan Prehistorik, Sumer, Akad-Yeni Sumer, Asur, Akamenid ve Selçuklu, Pers ve Sasani, İslami olarak adlandırılan yedi holden gezintiye devam edilebilmektedir.

\section{SONUÇ}

Dijital çağın gerektirdiği gibi döneme uyum sağlayan müzeler dijitalleşmeyi başka bir boyuta taşıyarak sanallaşmaya başlamışıtır. Müzelerin dijitalleşmesi henüz tartışması bitmemiş bir konu iken ortaya çıkan sanal müze kavramı, yaklaşık on yıllık geçmişine rağmen gölgededir. Ortak bir tanıma sahip olmayan sanal müzeler özünde semantik olarak kendi tanımını vermektedir. Gerçekte var olmayan zihinde tasarlanan anlamına gelen sanal bu bağlamda bir tanım ortaya koymak için kullanılabilir özellik taşımaktadır. Sanal müzeler bir anlamda Platon'un ideler dünyasındaki gibi gerçek nesnelerin birer yansımasıdır ancak bu nesneleri sanal kılan,onları bir arada fiziki koşullarda göremeyecek olmamızdır. Sanal müzelerin fiziken var olmayan müzeler olduğunu kabul ettiğimiz takdirde ,müzecilik otoriteleri (ICOM) tarafından tanımlarda eş anlamlı gibi kullanılan online müze, e-müze, dijital müze vb. kavramlarının aslında lafzen farklı yapılaşmalara işaret etmekte olduğunu söyleyebiliriz. Sanal müzelerin, sanata ya da geleneksel müze anlayışına zarar verip vermediği tartışması ise bir noktada sanal müzelerin kesin olarak tanımlanmamasından kaynaklanmaktadır. Kendine özgü bağımsız bir yapılaşma olan sanal müzeler, geleneksel müzelere bir rakip değildir aksine kendine ait bir deneyimi ve hissi olup destekleyici bir unsurdur. Bu sorunun bir başka kaynağ ise sanal müze kavramının uygun olmayan yapılaşmalarda dijital müze, online müze gibi kavramlar yerine kullanılmasıdır. Fiziki müzelere ziyaretçi çekmek amacıyla kurulan web sitelerde, sanal müze kavramının kullanılması birçok kişi tarafından sanatın ve kültürün metalaşması olarak algılanmaktadır. Oysaki sanal müzeler bir çok müzenin aksine tamamen ücretsizdir ve herhangi bir pazarlama kaygısı içermez. Bu sorunun çözümü ise ancak, sanal müzelerin ortak ve tam bir tanımının yapılması ve ayrıca bu kavramın kullanımının yasal bir denetlemeden geçmesi ile söz konusu olabilir. 
Sanal müze kavramının doğru yerde doğru şekilde kullanılması halinde oluşan ön yargılar yavaş yavaş ortadan kalkacaktır. Sanal müzelerin gerekliliği hakkında yapılan tartışmalar ise tamamen farklı bir açıdan değerlendirilmelidir. Dünyanın bir ucundan öbür ucuna hizmet veren sanal müzeler sadece uzaklıkları kapatacak, mümkün olmayan müze ziyaretlerini gerçekleştirecek bir yapılaşma olarak görülmemeli aynı zamanda büyük bir arşiv ve kaynak olarak değerlendirilmedir. Fiziki yapılar herhangi bir durumda doğal ve insan kaynaklı felaketlerden içindekilerle birlikte etkilenmektedir. Her zaman bir risk olan deprem, yangın, savaş, yağma ya da son günlerde giderek artan terör eylemleri, dünya mirası ya da sanat eseri ayırt etmeden yok etmektedir. Sanal müzeler, bu tip olaylara bir çözüm olmasa da, dünya mirasını korumak ve arşivlemek adına kullanılabilecek organize bir yapılaşmadır. Bu düşünceler doğrultusunda sanal müzeler, doğru koşullarda ve yapılanmalarda, fiziki müzelerin aksine kültür endüstrisinin bir parçası haline gelmeden, sayısal ve niteliksel olarak artırılmalıdır. İnternet üzerinde dolaşan ve giderek artan asılsız bilgiler karşısında sanal müzeler, dünyanın her yerinden her zaman doğru ve güvenilir bilgiye ulaşacağımız kaynaklar olarak var olacaktır.

\section{KAYNAKÇA}

Artun, Ali, "İnsanlık Tarihi Yeniden Müzeleştiriliyor",http://www.e-skop.com/ skopbulten/ insanliktarihi-yeniden-muzelestiriliyor/2665, 2015.

Barlas Bozkuş, Şeyda. (2014) "Kültür ve Sanat İletişimi Çerçevesinde Türkiye'de Sanal Müzelerin Gelişimi", The Journal of Academic Social Science Studies, no:26, sf.329-344.

International Council of Museums, http://icom.museum/, 2015.

Kubat,Ö.Z.(2012). "Sanal Müze Arayüz Tasarımı (Ressam Ahmet Yakupoğlu Sanal Müze Uygulaması)", T.C. Dumlupınar Üniversitesi Sosyal Bilimler Enstitüsü Grafik Ana Sanat Dalı Yüksek Lisans Tezi, Kütahya.

Lewis, Geoffry. (2011). The history of museums." Encyclopaedia Britannica 24.

Lin Hsin Hsin Art Museum, http://www.lhham.com.sg/, 2015.

MOCA, "Introducing Ourselves", http://moca.virtual.museum/about.htm, 2015.

Müze Asist, http://www.muzeasist.com/, 2015.

Peker,Neşe.(2014).Sosyal Bilgiler Dersinde Sanal Müze Kullanımı ve Sosyal Bilgiler Öğretmeni Adaylarının Sanal Müze Kullanımına Yönelik Tutumları, T.C. Aksaray Üniversitesi Sosyal Bilimler Enstitüsü Sosyal Bilgiler Eğitimi Anabilim Dalı Yüksek Lisans Tezi, Aksaray.

Rouse, Margaret.(2005). "Digital", http://whatis.techtarget.com/definition/digital.

Sağdıç, Ruhi Oğuz.(2008). Abidin Elderoğlu Sanal Müzesi Tasarımı, Hacettepe Üniversitesi Sosyal Bilimler Enstitüsü Grafik Ana Sanat Dalı, Yüksek Lisans Tezi, Ankara.

Sanal Müze (Arşiv), http://www.sanalmuze.org/index.php,2015.

Shweibenz,Werner.(1998)."The "Virtual Museum": New Perspectives For Museums to Present Objects and Information Using the Internet as a Knowledge Base and Communication System", 6. Internationalen Symposiums für Informationswissenschaft, Prag, 3-7 Kasım 1998, p. 185-200.

Shweibenz,Werner.(2004)."The Development of Virtual Museums", ICOM News, no:3.

Smithsonian Education, http://www.smithsonianeducation.org/index.html, 2015.

T.C. Kültür ve Turizm Bakanlığ1, "Sanal Gezinti", http://www.kultur.gov.tr/TR,28896/sanalgezinti.html, 2015.

TDK, "Güncel Türkçe Sözlük" , http://tdk.gov.tr/index.php?option=com_gts\&arama=gts\& guid =TDK.GTS.56432f012307c8.60280478, 2015.

The Editors of Encyclopaedia Britannica, "Virtual Museum",http://global.britannica.com/ topic/virtual-museum, 2015.

The Iraq Museum,"About the Museum", http://www.iraqmuseum.org/pages/about-the-museum/, 2015.

The Public's Library and Digital Archive, www.ibiblio.org, 2015.

The Virtual Museum of Iraq, http://www.virtualmuseumiraq.cnr.it/prehome.htm, 2015.

Torun, Ayla.(2015)."Walter Benjamin, Sanat Eserinin Auras1 ve Yeni Medya Sanatı", International Multilingual Academic Journal, 2(1).

Yengin,Deniz.(2014)."Yeni Medya ve Dokunmatik Toplum", Derin Yayınları, İstanbul, 2.Bask1. 